Mycologia, 91(6), 1999, pp. 1060-1082.

(C) 1999 by The Mycological Society of America, Lawrence, KS 660448897

\title{
Trichomycetes in Argentinean aquatic insect larvae
}

\author{
Robert W. Lichtwardt ${ }^{1}$ \\ Department of Ecology and Evolutionary Biology, \\ University of Kansas, Lawrence, Kansas 66045-2106 \\ Leonard C. Ferrington, Jr. \\ Department of Entomology and Kansas Biological \\ Survey, Foley Hall, West Campus, University of \\ Kansas, Lawrence, Kansas 66047-2906 \\ Claudia López Lastra \\ Centro de Estudios Parasitológicos y de Vectores, \\ CONICET Scientific Researcher, Calle $2 N^{\circ} 584$, \\ La Plata, Argentina
}

\begin{abstract}
Investigations of larval aquatic Diptera (Chironomidae, Simuliidae, Culicidae), Coleoptera (Scirtidae), and Plecoptera (Gripopterygidae, Notonemouridae) in Buenos Aires Province and three Provinces in Patagonia (Río Negro, Chubut, Neuquén) have revealed 19 species of gut fungi (Zygomycota: Trichomycetes). Three of the species represent new monotypic genera: Coleopteromyces amnicus, Plecopteromyces patagoniensis, and Stachylinoides arctata. This is the first report of a Harpellales living in a Coleoptera larva. New species were Carouxella coemeteriensis, Paramoebidium digitoideum, Smittium esteparum, S. tronadorium, and Stachylina platensis. In addition, what may be new species of Smittium and Stachylina are described but not named. Two of the species, Harpella meridianalis and Smittium cylindrosporum, were previously know only from southern Chile. The other six previously described species found in Argentina have a wider geographic distribution, including Smittium morbosum which is pathogenic to mosquito larvae. A key to Argentinean species of Trichomycetes and comments on their biogeography are provided.

Key Words: biogeography, Coleoptera, Diptera, gut fungi, Harpellales, Patagonia, Plecoptera, symbiosis
\end{abstract}

\section{INTRODUCTION}

The class Trichomycetes (Zygomycota) consists of a worldwide group of fungi that live obligately within

Accepted for publication June 24, 1999.

${ }^{1}$ Email: licht@eagle.cc.ukans.edu the guts of several taxa of Arthropoda. Their symbiotic relationships may be either commensalistic, pathogenic, or, at times, mutualistic (Horn and Lichtwardt 1981, Lichtwardt 1986, 1996). Emphasis in this study is on the trichomycete order Harpellales whose species are found living in the hindgut or midgut of aquatic insect larvae. Species of the other two widespread trichomycete orders, Asellariales (in Isopoda and Collembola) and Eccrinales (in Crustacea, Insecta, and Diplopoda) have now been found in Argentina, as expected, but they will be discussed in other forthcoming publications.

Studies on harpellid gut fungi inhabiting insect larvae in South America are sparse, although there is little question that Harpellales are as common and diverse on that continent as they are in the rest of the world, and that numerous new taxa are yet to be discovered. The only published account of Harpellales in South America outside of Argentina was a paper by Lichtwardt and Arenas (1996) on 11 species of Harpellales, five of them new, found during a fourweek study in the Valdivia region of southern Chile. Prior to our investigations reported in this article, species of Harpellales in Argentina had been studied in mosquito (Culicidae) larvae by several researchers (Campos et al 1995, García et al 1994, 1995, Maciá et al 1995, 1996-1997), including a report of a new variety of Smittium morbosum Sweeney that was lethal to several genera and species of mosquito larvae in Buenos Aires Province (López Lastra 1990).

We report here the finding of 19 species, three representing new monotypic genera. One of the new genera, Plecopteromyces, was found in two species of the Plecoptera (stonefly) family Gripopterygidae which has a circumantarctic distribution. The second new genus, Coleopteromyces, was found in aquatic larvae of Scirtidae (Coleoptera), which is the first record of a harpellid in a beetle host; prior to this report, the only published hosts of Harpellales have been nymphs of Plecoptera, Ephemeroptera (mayflies), larvae of lower Diptera in the suborder Nematocera, and isopods (White 1999). The third new genus, Stachylinoides, was found in a minute species of Chironomidae (midge); Stachylinoides resembles Stachylina, both of whose species commonly inhabit chironomid larvae.

The gut fungi encountered and their insect host 
families, in parentheses, were: Carouxella coemeteriensis (Ceratopogonidae), Coleopteromyces amnicus (Scirtidae), Genistellospora homothallica (Simuliidae), Harpella meridianalis (Simuliidae), Paramoebidium digitoideum (Notonemouridae), Plecopteromyces patagoniensis (Gripopterygidae), Simuliomyces microsporus (Simuliidae), Smittium culicis (Culicidae), Smittium culisetae (Culicidae), Smittium cylindrosporum (Chironomidae), Smittium estaparum (Chironomidae), Smittium megazygosporum (Chironomidae), Smittium morbosum (Culicidae), Smittium tronadorium (Chironomidae), Smittium sp. (Chironomidae), Stachylina minima (Chironomidae), Stachylina platensis (Chironomidae). Stachylina sp. (Chironomidae), and Stachylinoides arctata (Chironomidae). All fungi are Harpellales, except for $P$. digitoideum (Amoebidiales), and all host families are Diptera, except for Scirtidae (Coleoptera), and Gripopterygidae and Notonemouridae (Plecoptera).

\section{MATERIALS AND METHODS}

Our investigations were centered in two areas of Argentina, one that included parts of several provinces in Patagonia (Río Negro, Chubut, Neuquén), the other in Buenos Aires Province (FIG. 1, TABLE I). Collections of aquatic insect larvae in streams and rivers were made using nets and pans, or by selecting insects directly from their substrates. In ponds, pools and other lentic habitats nets, food strainers, or large kitchen basters were used. Lotic living insects were kept on ice until dissected in the laboratory. Fungal specimens were examined under microscopes equipped with phase contrast or differential interference contrast optics, and were first studied in a living condition in water mounts, and photographed in most instances before the slides were made permanent by infiltration with lactophenol-cotton blue and sealed with clear fingernail polish. Dissected or intact hosts were preserved in $70 \%$ ethanol for later identification.

Attempts to culture some of the Harpellales were made by selecting pieces of gut in which fungal thalli were growing and washing them at least twice in $35-\mathrm{mm}$ petri dishes containing sterile distilled water with a penicillin-streptomycin antibiotic mixture, then transferring the specimens to $60 \mathrm{~mm}$ petri dishes containing dilute brain-heart infusion agar medium with a thin overlay of sterile distilled water and antibiotics, all according to procedures outlined by Lichtwardt (1986). Successful cultures are deposited in culture collections as noted under individual fungal names. Selected fungi were preserved in $2 \times$ CTAB DNA extraction buffer for later molecular studies.

\section{NEW GENERA AND SPECIES}

Carouxella coemeteriensis Lichtw., López Lastra et Ferrington, sp. nov. Figs. 2-8

Thalli sine ramis ad proctodaei cuticulam affixi, usque ad $800 \mu \mathrm{m}$ longi, cerca $7 \mu \mathrm{m}$ diametro, basi haud incurva.

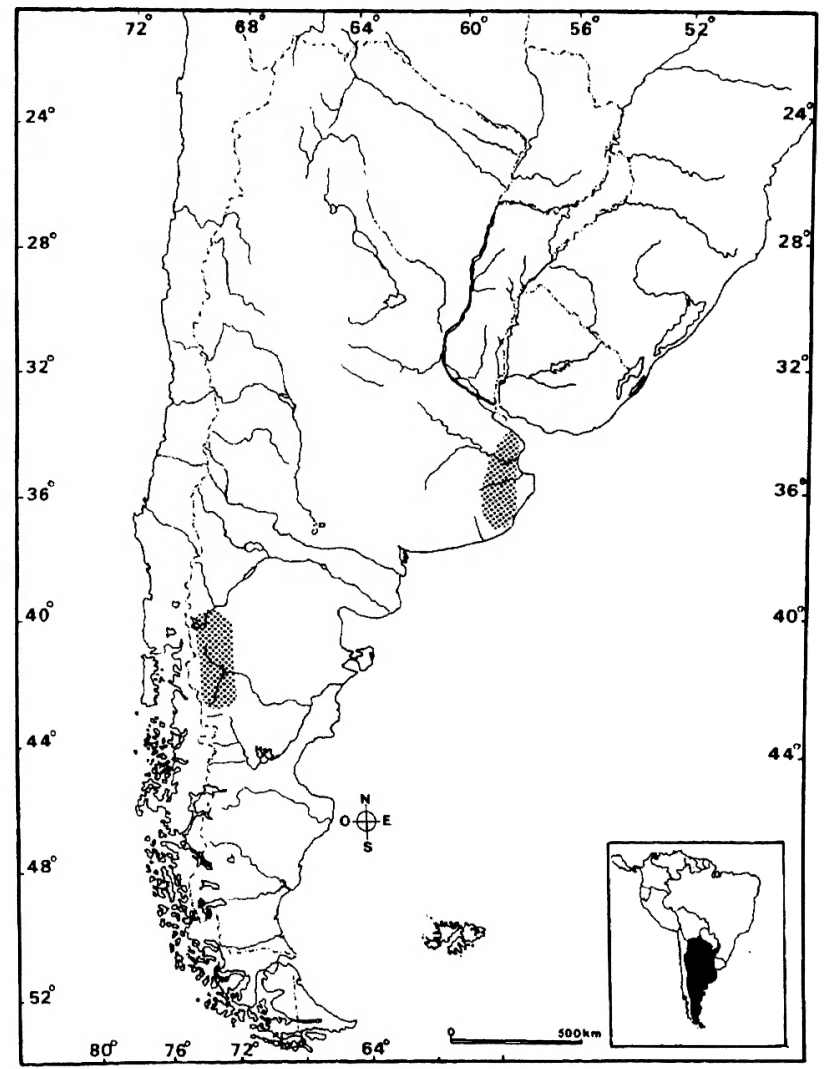

FIG. 1. Regions in Argentina where Trichomycetes were collected. These include parts of Buenos Aires Province and parts of Chubut, Neuquén, and Río Negro Provinces in $\mathrm{Pa}-$ tagonia.

Cellulas genitales non faciliter separabiles producentes. Trichosporae breviter cylindricae, ad medium parum expansae, 27-38 $\times$ 5.5-7.5 $\mu \mathrm{m}$, maturae ad cellulam genitalem affixae. Zygosporae (Figurae IV) 38-41 × $6 \mu \mathrm{m}$; zygosporophorum 30-36 × 5-5.5 $\mu \mathrm{m}$. In Ceratopogonidarum larvis.

Unbranched thalli attached to hindgut cuticle, up to $800 \mu \mathrm{m}$ long by about $7 \mu \mathrm{m}$ diam, base not incurved. Producing generative cells that do not easily disarticulate. Trichospores short-cylindrical with a slight median bulge, $27-38 \times 5.5-7.5 \mu \mathrm{m}$, remaining attached to generative cell after maturing. Zygospores (Type IV) 38-41 ×6 $\mathrm{\mu m}$; zygosporophore 30$36 \times 5-5.5 \mu \mathrm{m}$. In larval Ceratopogonidae.

Etymology. Gr. koimeterion = burial place.

Specimens examined. ARGENTINA. BUENOS AIRES: Cementerio La Plata, La Plata, from a water-containing flower vase on a grave, $34^{\circ} 57.5^{\prime} \mathrm{S}, 57^{\circ} 57.8^{\prime} \mathrm{W}, 27-\mathrm{XI}-96$, microscope slide ARG-39-14 (HOLOTYPE) (shows two conjugating thalli with trichospores and zygospores) prepared from a larva of Dasyhelea necrophila Spinelli \& Rodriguez (Diptera: Ceratopogonidae). ISOTYPES. From same collection and host species as the holotype, microscope slide ARG-39-1 (with trichospores only) and microscope slide ARG-39-8 (a mass of conjugating thalli with zygospores and a few trichospores). 
TABLE I. Sites in Argentina from which trichomycete-infected aquatic insect larvae were obtained in $1996^{\mathrm{a}}$

\begin{tabular}{|c|c|c|c|}
\hline Site $^{b}$ & Stream or other habitat & Date & Longitude/latitude \\
\hline 2 & Arroyo La Virgen & 2-XI-96 & $41^{\circ} 06.3^{\prime} \mathrm{S}, 71^{\circ} 29.1^{\prime} \mathrm{W}$ \\
\hline 3 & Arroyo Casa de Piedra & 2-XI-96 & $41^{\circ} 07.8^{\prime} \mathrm{S}, 71^{\circ} 27.2^{\prime} \mathrm{W}$ \\
\hline 4 & Arroyo Gutiérrez & 2-XI-96 & $41^{\circ} 08.0^{\prime} \mathrm{S}, 71^{\circ} 25.0^{\prime} \mathrm{W}$ \\
\hline 5 & Cañada de los Bandidos & $6-X I-96$ & $42^{\circ} 54.2^{\prime} \mathrm{S}, 71^{\circ} 17.8^{\prime} \mathrm{W}$ \\
\hline 6 & Arroyo Esquel & $6-\mathrm{XI}-96$ & $42^{\circ} 54.8^{\prime} \mathrm{S}, 71^{\circ} 17.5^{\prime} \mathrm{W}$ \\
\hline 7 & Arroyo Esquel & $6-X I-96$ & $42^{\circ} 55.0^{\prime} \mathrm{S}, 71^{\circ} 17.5^{\prime} \mathrm{W}$ \\
\hline 9 & Arroyo Baquille & 6-XI-96 & $42^{\circ} 55.0^{\prime} \mathrm{S}, 71^{\circ} 17.5^{\prime} \mathrm{W}$ \\
\hline 10 & Arroyo Rodeo & 6-XI-96 & $42^{\circ} 48.8^{\prime} \mathrm{S}, 71^{\circ} 07.0^{\prime} \mathrm{W}$ \\
\hline 11 & Arroyo El Montoso & 6-XI-96 & $42^{\circ} 44.3^{\prime} \mathrm{S}, 71^{\circ} 05.8^{\prime} \mathrm{W}$ \\
\hline 12 & Arroyo Lepá & 6-XI-96 & $42^{\circ} 36.8^{\prime} \mathrm{S}, 71^{\circ} 04.7^{\prime} \mathrm{W}$ \\
\hline 15 & Arroyo López & $11-X I-96$ & $41^{\circ} 06.3^{\prime} \mathrm{S}, 71^{\circ} 29.1^{\prime} \mathrm{W}$ \\
\hline 16 & Arroyo La Virgen & $11-X I-96$ & $41^{\circ} 06.3^{\prime} \mathrm{S}, 71^{\circ} 29.1^{\prime} \mathrm{W}$ \\
\hline 17 & Unnamed small stream, trib. of Rio Traful & $12-\mathrm{XI}-96$ & $40^{\circ} 43.0^{\prime} \mathrm{S}, 71^{\circ} 06.0^{\prime} \mathrm{W}$ \\
\hline 18 & Arroyo Córdoba Grande & $12-X I-96$ & $40^{\circ} 30.8^{\prime} \mathrm{S}, 71^{\circ} 12.2^{\prime} \mathrm{W}$ \\
\hline 19 & Arroyo Futa Liú & $12-X I-96$ & $40^{\circ} 21.9^{\prime} \mathrm{S}, 71^{\circ} 18.8^{\prime} \mathrm{W}$ \\
\hline 20 & Arroyo Culebra & $12-\mathrm{XI}-96$ & $40^{\circ} 15.7^{\prime} \mathrm{S}, 71^{\circ} 23.1^{\prime} \mathrm{W}$ \\
\hline 21 & Arroyo Neuquencó & 13-XI-96 & $40^{\circ} 37.3^{\prime} \mathrm{S}, 71^{\circ} 39.9^{\prime} \mathrm{W}$ \\
\hline 22 & Unnamed stream, Rt. 231 & $13-\mathrm{XI}-96$ & $40^{\circ} 50.2^{\prime} \mathrm{S}, 71^{\circ} 32.3^{\prime} \mathrm{W}$ \\
\hline 24 & Unnamed tributary of R. Manso Superior & $17-X I-96$ & $41^{\circ} 12.1^{\prime} \mathrm{S}, 71^{\circ} 49.6^{\prime} \mathrm{W}$ \\
\hline 25 & Small stream, trib. of R. Manso Superior & $17-\mathrm{XI}-96$ & $41^{\circ} 12.5^{\prime} \mathrm{S}, 71^{\circ} 49.0^{\prime} \mathrm{W}$ \\
\hline 28 & Swamp in woods, Boca Cerrada & 22-XI-96 & $34^{\circ} 47.0^{\prime} \mathrm{S}, 58^{\circ} 00.7^{\prime} \mathrm{W}$ \\
\hline 31 & Swamp in woods, Boca Cerrada & 24-XI-96 & $34^{\circ} 47.0^{\prime} \mathrm{S}, 58^{\circ} 00.7^{\prime} \mathrm{W}$ \\
\hline 32 & Cementerio La Plata & 24-XI-96 & $34^{\circ} 57.5^{\prime} \mathrm{S}, 57^{\circ} 57.8^{\prime} \mathrm{W}$ \\
\hline 39 & Cementerio La Plata & $27-\mathrm{XI}-96$ & $34^{\circ} 57.5^{\prime} \mathrm{S}, 57^{\circ} 57.8^{\prime} \mathrm{W}$ \\
\hline 41 & Arroyo Grande & 30-XI-96 & $37^{\circ} 3^{\prime} \quad \mathrm{S}, 57^{\circ} 4^{\prime} \quad \mathrm{W}$ \\
\hline 42 & Arroyo Dulce & $30-X I-96$ & $37^{\circ} 37.4^{\prime} \mathrm{S}, 57^{\circ} 40.7^{\prime} \mathrm{W}$ \\
\hline 43 & Arroyo Vivoratá & 30-XI-96 & $37^{\circ} 44.2^{\prime} \mathrm{S}, 57^{\circ} 38.9^{\prime} \mathrm{W}$ \\
\hline 44 & Arroyo Las Brusquitas & $30-\mathrm{XI}-96$ & $38^{\circ} 07.6^{\prime} \mathrm{S}, 57^{\circ} 49.0^{\prime} \mathrm{W}$ \\
\hline $46 a$ & Arroyo El Crespo & $1-X I I-96$ & $37^{\circ} 44.2^{\prime} \mathrm{S}, 58^{\circ} 21.2^{\prime} \mathrm{W}$ \\
\hline $46 \mathrm{~b}$ & Arroyo Napaleofú & 1-XI-96 & $37^{\circ} 27.6^{\prime} \mathrm{S}, 58^{\circ} 28.7^{\prime} \mathrm{W}$ \\
\hline 47 & Arroyo El Perdido & 1-XI-96 & $36^{\circ} 48.6^{\prime} \mathrm{S}, 58^{\circ} 33.9^{\prime} \mathrm{W}$ \\
\hline 48 & Swamp in woods, Boca Cerrada & 3-XII-96 & $34^{\circ} 47.0^{\prime} \mathrm{S}, 58^{\circ} 00.7^{\prime} \mathrm{W}$ \\
\hline
\end{tabular}

a Other collecting sites prior to 1996 are provided under individual trichomycete species.

${ }^{\mathrm{b}}$ Sites 2-4, 15-16 and 24-25 are in Río Negro Province; Sites 5-12 in Chubut Province; Sites 17-22 in Neuquén Province; Sites 28-48 in Buenos Aires Province.

(FH). Other specimens from several flower vases on graves at Cementerio La Plata 24-X-96 (TABLE I, Site 32) and 27XI-96 (Site 39).

The type species, Carouxella scalaris Manier \& Lichtw., was described from larvae of Dasyhelea lithotelmatica Strenzk collected in troughs, potholes, and rocky fissures from the southern France Provinces of Hérault and Pyrénées-Orientales (Manier et al 1961, Manier and Lichtwardt 1968). Another Carouxella with thallial and trichospore features that appeared to be identical to $C$. scalaris (but without zygospores for confirmation) was found in larvae of an undescribed species of Dasyhelea breeding in potholes above the Georges River in New South Wales, Australia (Lichtwardt and Williams 1990). To this unusual disjunct distribution of Carouxella in different species of Dasyhelea larvae we now add, from Argentina, a second species of the fungal genus living in yet another species of Dasyhelea.

Thalli of $C$. scalaris are unusual in that trichospores do not release as they normally do in other Harpellales. Rather, trichospores remain attached to their generative cells which then disarticulate from each other so as to form trichospore/generative cell units that function as propagules. We were not able to see either disarticulation of the thallic cells nor release of trichospores in $C$. coemeteriensis, even when specimens were kept in water cultures for extended periods of time. On two occasions loose trichospores were seen in fresh slide preparations, but this may have resulted from excessive handling of the specimens. Another way in which $C$. coemeteriensis differs from $C$. scalaris is that the basal part of the thallus of the latter species is normally incurved with the 

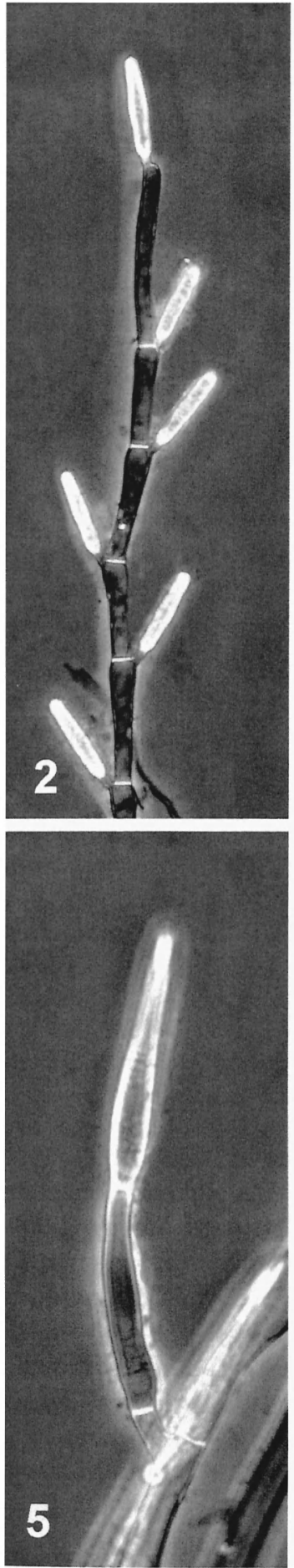
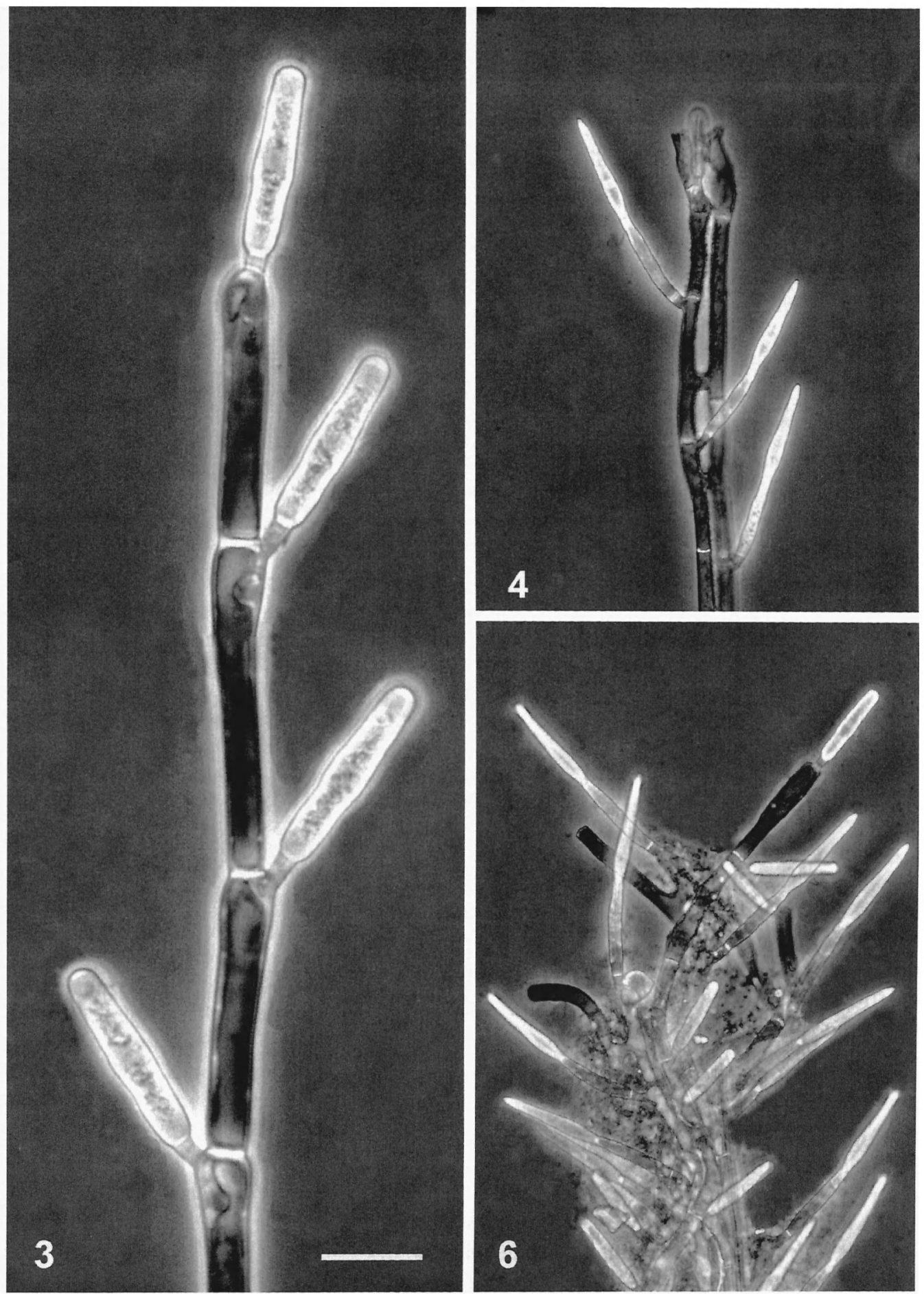

FIGS. 2-6. Carouxella coemeteriensis. 2. Terminal part of an unbranched thallus producing trichospores. 3. Enlarged view of mature trichospores. 4. Two conjugating thalli that have produced zygospores. 5. Enlarged view of a mature zygospore. 6 . A group of conjugating thalli bearing both trichospores (rounded tips) and zygospores (pointed tips). Scale bar: $2,4,6=$ $40 \mu \mathrm{m} ; 3,5=20 \mu \mathrm{m}$.

holdfast located in the inner part of the curve (Manier et al 1961), whereas the thallic bases in C. coemeteriensis were always straight (FIG. 7). Trichospores of the two species are approximately the same size, but the zygospores of C. coemeteriensis are slightly longer: $38-41 \mu \mathrm{m}$ vs $35 \mu \mathrm{m}$ for $C$. scalaris.

Young thalli of $C$. coemeteriensis usually were seen attached to the anterior hindgut, with the thalli grow- 

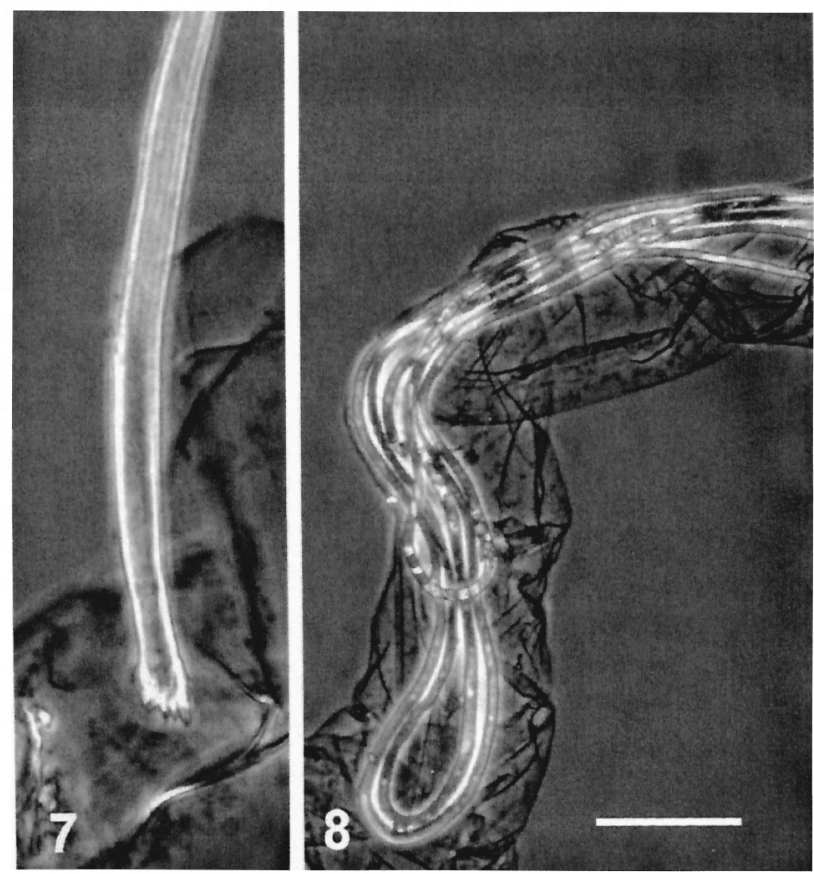

FIGS. 7-8. Carouxella coemeteriensis. 7. Holdfast region of a thallus. 8. Pattern of folding backward typical of more mature thalli, the posterior part of the hindgut cuticle is at the upper right. Scale bar: $7=20 \mu \mathrm{m} ; 8=80 \mu \mathrm{m}$.

ing in a posterior direction, as normally happens in other Harpellales. However, as the tip of the thallus grows, the basal region of the thallus bends or is forced backward toward the midgut (FIG. 8), and in one case the crooks at the base of the thalli were seen lying within the midgut. Thalli more commonly produce only trichospores (FIGS. 2, 3), but larvae we left in their native water in laboratory containers for many days began to show conjugations between and among thalli, leading to mature zygospore formation (FIGS. 4, 5). Thalli with scalariform conjugations often produced trichospores from cells that had not conjugated. Such unconjugated cells with trichospores (rounded tips) were either terminal or intercalary (FIG. 6).

Many of the cemetery flower vases from which collections were made held old, decomposing flowers and contained various kinds of aquatic organisms in the accumulated rainwater. Mosquito larvae were common, but fewer vases contained ceratopogonids. Of the 295 Dasyhelea larvae we dissected, 60 were infected with $C$. coemeteriensis. This total includes ceratopogonids from many vases that did not contain infected larvae. The mechanism by which $C$. coemeteriensis was recruited into some of the vases containing ceratopogonid populations is unknown, but conceivably it was introduced by "ovipositing" females whose ovaries were infected with cysts of $C$. coemeter- iensis, as occurs in other species of Harpellales in Simuliidae (Labeyrie et al 1996, Lichtwardt 1996). It is likely that, once introduced into breeding populations of the larvae, the fungus spreads from larva to larva, as we have frequently demonstrated to happen in the laboratory in mosquito populations that become infected with Smittium culisetae Lichtw. or $S$. culicis Manier.

Coleopteromyces Ferrington, Lichtw. et López Lastra, gen. nov.

Thallorum axis principuus rare ramosus, in proctodaeo larvarum Scirtidarum (Coleoptorum). Trichosporae elongato-ellipsoideae, collari parvo, appendiculo uno. Zygosporae ignotae.

Thalli with a main axis, sparsely branched, in hindgut of larvae of Scirtidae (Coleoptera). Trichospores long-ellipsoidal with a small collar and single appendage. Zygospores unknown.

Etymology. Fungus from a coleopteran.

Type species. Coleopteromyces amnicus Ferrington, Lichtw. \& López Lastra

Coleopteromyces amnicus Ferrington, Lichtw. et López Lastra, sp. nov. FIGS. 9-12

Thalli usque ad $2 \mathrm{~mm}$ longitudine, axe principuo ramos fertiles plures 4-8 $\mu \mathrm{m}$ diametro gignente. Rami steriles aliqui tam anguste quam $2 \mu \mathrm{m}$. In ramo uno cellulae genitales ad 12 numero, trichosporas elongato-ellipsoidales (28-) $33(-37) \times 6-7 \mu \mathrm{m}$, liberatas collarem parvum ad trichosporae corpus anguste connectum ornatas et appendiculo uno. Zygosporae ignotae. Ad proctodaei cuticulam larvarum Scirtidarum (Coleopterorum) loticarum affixi.

Thalli up to $2 \mathrm{~mm}$ long with a sparsely branched main axis producing several fertile branches $4-8 \mu \mathrm{m}$ diameter. Some sterile branches as narrow as $2 \mu \mathrm{m}$ diameter. Up to 12 generative cells per branch, producing long-ellipsoidal trichospores (28-)33(-37) $\times$ 6-7 $\mu \mathrm{m}$, upon release having a small collar attached by a narrow connection to the trichospore body, with a single appendage longer than the spore. Zygospores unknown. Attached to hindgut cuticle of lotic Scirtidae (Coleoptera) larvae.

Etymology. L. amnicus, of a stream.

Specimens examined. ARGENTINA. RÍO NEGRO: Arroyo La Virgen, $41^{\circ} 06.3^{\prime} \mathrm{S}, 71^{\circ} 29.1^{\prime} \mathrm{W}, 11-\mathrm{XI}-96$, microscope slide ARG-16-3 (HOLOTYPE) prepared from a lotic Scirtidae larva on a submerged log. From same collection and host species as the holotype, microscope slide ARG-16-2 (ISOTYPE). (FH). Additional specimens from Scirtidae larvae collected 2-XI-96 and 11-XI-96 in Arroyo La Virgen (TABLE I, Sites 2 and 16); from Arroyo López, 11-XI-96 (Site 15); and from Arroyo Córdoba Grande, 12-XI-96 (Site 18).

Coleopteromyces amnicus is the first Harpellales described from a host other than a dipteran, ephem- 

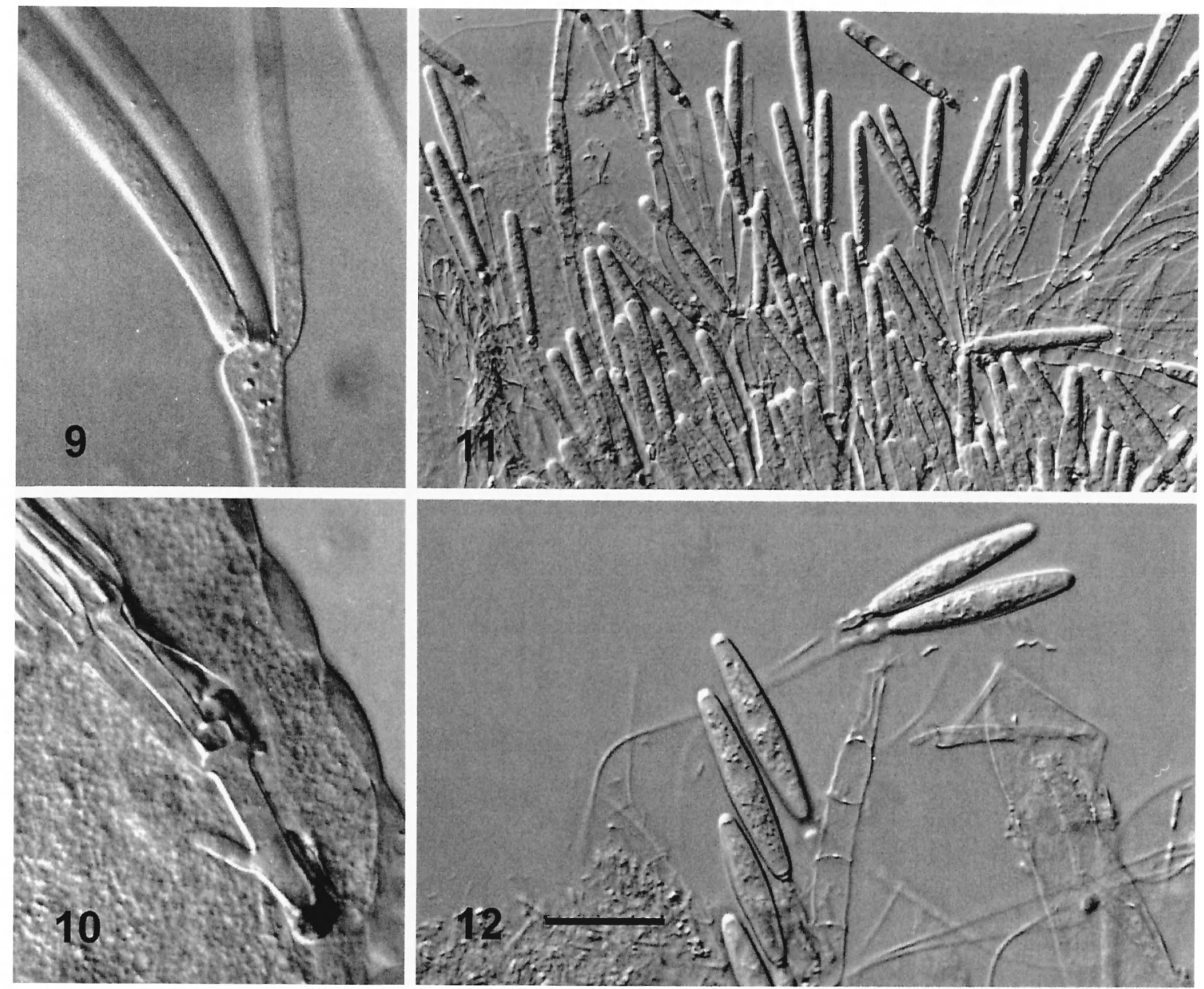

FIGS. 9-12. Coleopteromyces amnicus. 9. Branching pattern, giving rise to narrower branches that become fertile. 10. Holdfast at base of a thallus inside the hindgut of a beetle larva. 11. Mass of trichospores, with a few having detached from their generative cells. 12. Two detached trichospores each with a single appendage. Scale bar: 9, 10, $12=20 \mu \mathrm{m} ; 11=40 \mu \mathrm{m}$.

eropteran, or plecopteran. The fungus is also distinguished by its very long, sparsely branched thallus. The ellipsoidal trichospores have a small, somewhat rounded collar that is usually (but not always) attached to the spore body by a short isthmus. This is a feature not present in Smittium trichospores, which most closely resemble those of $C$. amnicus. The single appendage is relatively wide (FIG. 12). In one specimen from Site 2 there was a long filament trailing from two of the released trichospores, these were determined not to be appendages but rather ends of filamentous prokaryotes attached to the collar. Such long, filamentous prokaryotes were common in the hindguts of the beetles.

The Scirtidae (= Helodidae) beetles, commonly called marsh beetles, were collected on the surfaces of logs that were submerged in flowing areas of streams. More than half of the beetles dissected were infected with $C$. amnicus. The hindgut of Scirtidae larvae is elongate, extends posteriorly for a distance, then bends anteriorly before bending again posteriorly to the anus. Fungal growths were typically attached to the anterior part of the hindgut before the first bend. The elongate thalli of mature fungal growths often extended through nearly the entire hindgut, with trichospores developing near the apex of the thallus just before the anus of larvae.

Five attempts to culture this new fungus were unsuccessful.

Paramoebidium digitoideum Ferrington, Lichtw. et López Lastra, sp. nov.

Figs. 13-16

Thalli re vera recti, cylindrici, ad $340 \mu \mathrm{m}$ longi, 10-22 $\mu \mathrm{m}$ diametro, tenaculo inconspicuo basali. Ad cuticulam proctodaei Plecopterorum (Notonemouridorum) affixi.

Thalli essentially straight and cylindrical, up to 340 $\mu \mathrm{m}$ long by $10-22 \mu \mathrm{m}$ diam, with an inconspicuous basal holdfast. Attached to hindgut cuticle of Plecoptera (Notonemouridae). 

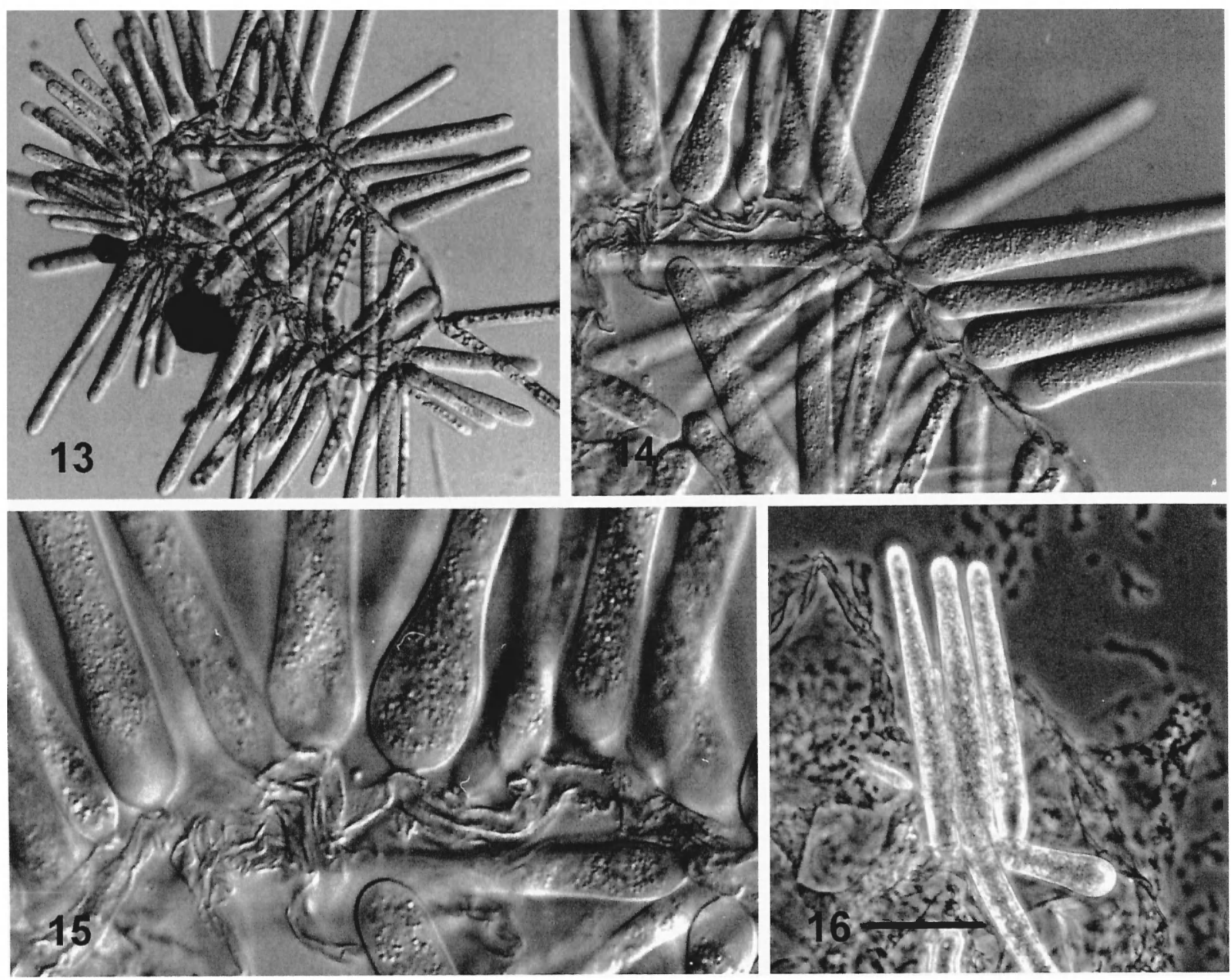

Figs. 13-16. Paramoebidium digitoideum. 13-15. Clusters of thalli attached to a piece of hindgut cuticle; note membranous structure at the bases of thalli in 15. 16. A small cluster of immature thalli. Scale bar: $13=80 \mu \mathrm{m} ; 14,16=40 \mu \mathrm{m} ; 15=$ $20 \mu \mathrm{m}$.

Etymology. L. digitoides $=$ fingerlike.

Specimens examined. ARGENTINA. RÍO NEGRO: small stream, tributary of Río Manso Superior, $41^{\circ} 12.5^{\prime} \mathrm{S}, 71^{\circ}$ 49.0' W, 17-XI-96, microscope slide ARG-25-5F (HOLOTYPE) containing fungus from a nymph of Austronemoura sp. (Insecta: Notonemouridae). (FH). ARG-25-10, microscope slide from same site and host as holotype; ARG-19-9F, Arroyo Futa Liú, $40^{\circ} 21.9^{\prime} \mathrm{S}, 71^{\circ} 18.8^{\prime} \mathrm{W}, 12-\mathrm{XI}-96$, microscope slide of fungus from an Austronemoura nymph.

The unusual thallial shape for a Paramoebidium distinguishes $P$. digitoideum from other species of the genus. Amoebae were not released in our specimens. This is the first report of a trichomycete from the circumantarctic stonefly family Notonemouridae.

In one larva there were numerous immature thalli growing in close proximity to each other and forming a circular arrangement. Thalli appeared to be intermingled or attached by a basal membrane (FIG. 15) which may have been an infolding of the inner lining of the hindgut wall.
Plecopteromyces Lichtw., Ferrington et López Lastra, gen. nov.

Trichosporae elongato-ellipsoidales, sine collari, appendiculas latas singulas vel binas gerentes. Zygosporae (Figurae IV) turbinatae, per finem latiorem ad zygosporophorum affixae. In Plecopterorum nymphis.

Trichospores long-ellipsoidal, without a collar, bearing one or two broad appendages. Zygospores (Type IV) turbinate, attached to zygosporophore at broader end. In Plecoptera nymphs.

Etymology. Fungus from a plecopteran.

Type species. Plecopteromyces patagoniensis Ferrington, Lichtw. \& López Lastra

Plecopteromyces patagoniensis Lichtw., Ferrington et López Lastra, sp. nov. FIGS. 17-26

Thalli sparse ramosi, trichosporas longi-ellipsoidales, 14 tenus in omni ramo fertili producentes, trichosporae (25-) $33(-42) \times 5-7 \mu \mathrm{m}$, sine collari, appendiculas duas latas 
nonnumquam in unam conflatas producentes; zygosporae turbinatae, 15-17 $\times$ 8-9 $\mu \mathrm{m}$; zygosporophorum 20-40 $\times 6$ $8 \mu \mathrm{m}$, ex tuba conjugationis orta. In proctodaeo Gripopterygidarum nymphis.

Thalli with few branches, producing up to 14 longellipsoidal trichospores per fertile branch, trichospores (25-) $33(-42) \times 5-7 \mu \mathrm{m}$, without a collar with two broad appendages that may remain fused into one; zygospores turbinate, 15-17 × 8-9 $\mu \mathrm{m}$; zygosporophores $20-40 \times 6-8 \mu \mathrm{m}$, arising from the conjugation tube. In hindgut of Gripopterygidae nymphs.

Etymology. From Patagonia.

Specimens examined. ARGENTINA. NEUQUÉN: small unnamed tributary of Río Traful, $40^{\circ} 43.0^{\prime} \mathrm{S}, 71^{\circ} 06.0^{\prime} \mathrm{W}, 12-$ XI-96, microscope slide ARG-17-7. (HOLOTYPE) prepared from a nymph of Limnoperla jaffueli (Navás), with masses of zygospores. Microscope slide ARG-17-8 (ISOTYPE) from same collection and host species as holotype, with trichospores. (FH). Other specimens: in nymphs of either L. jaffueli or Aubertoperla illiesi (Froehlich) collected from Sites $4,11,15,16,17,18,20$, and 24 (TABLE I).

The new monotypic genus Plecopteromyces is most distinctive in the structure of its zygospore (FIGs. 2224). Type IV zygospores (Moss et al 1975) are a modification of the usual biconical zygospore shape, being attached at one end such that only the distal end is pointed. Three other genera of Harpellales produce Type IV zygospores: Carouxella, Lancisporomyces Santamaria, and Zygopolaris S. T. Moss, Lichtw. \& Manier. None of their zygospores is as small as Plecopteromyces patagoniensis, nor has its turbinate shape.

Also distinctive is the long-elliptical, collarless trichospore with its broad appendage(s). In some specimens there were distinctly two appendages (FIGs. 19, 21), whereas other trichospores had but one (FIG. 20). We believe the single appendage represents a lack of separation of the appendage material upon release of the trichospore.

Six attempts to culture $P$. patagoniensis were not successful.

Smittium esteparum Ferrington, Lichtw. et López Lastra, sp. nov.

Figs. 27-30

Thalli trichosporas gerentes vel subcylindricas 31-38 $\times$ 4.5-6.5 $\mu \mathrm{m}$, collari 4-6 $\mu \mathrm{m}$ longo, vel ellipsoidales ad medium inflatas, 12-14 $\times$ 4-5 $\mu \mathrm{m}$, collari $2 \mu \mathrm{m}$ longo. Zygosporae cerca $50 \times 10 \mu \mathrm{m}$; zygosporophorae cerca $30 \times 7-$ $8 \mu \mathrm{m}$, ad zygosporae dimidium medium inter medium et finem inferiorem affixa. In Chironomidarum larvis.

Thalli bearing both subcylindrical trichospores measuring 31-38 $\times 4.5-6.5 \mu \mathrm{m}$ with a collar 4-6 $\mu \mathrm{m}$ long, and ellipsoidal trichospores with a median bulge, $12-14 \times 4-5 \mu \mathrm{m}$ with a collar $2 \mu \mathrm{m}$ long. $\mathrm{Zy}-$ gospores about $50 \times 10 \mu$; zygosporophores about 30 $\times 7-8 \mu \mathrm{m}$, attached about half way between mid re- gion and lower end of zygospore. In larvae of Chironomidae.

Etymology. From the estepas (steppes of Patagonia). Specimens examined. ARGENTINA. CHUBUT: Arroyo Rodeo, crossing Highway 258/40, about $39 \mathrm{~km} \mathrm{~N}$ of Esquel (Site 10), $42^{\circ} 48.8^{\prime} \mathrm{S}, 71^{\circ} 07.0^{\prime} \mathrm{W}, 6-\mathrm{XI}-96$, Ektachrome photomicrograph ARG-D-28 (HOLOTYPE) of microscope slide ARG-10-8F prepared from an Orthocladiinae (Cricotopus sp.) larva (Diptera: Chironomidae). (FH). Other specimens: from Eukiefferiella sp. larvae (Orthocladiinae) collected same date and site as the holotype (Site 10, TABLE I), including one specimen with a zygospore (microscope slide ARG-10-4F); from one Cricotopus sp. larva (Orthocladiinae) (microscope slide ARG-24-12F) collected 6-XI-96 in an unnamed tributary of Río Manso Superior, $41^{\circ} 12.1^{\prime} \mathrm{S}$, $71^{\circ} 49.6^{\prime} \mathrm{W}$, Río Negro Province (Site 24), with dimorphic trichospores and one incipient zygospore.

Two other dimorphic Harpellales are known from Chironomidae larvae, but their trichospore shapes and dimensions are different from $S$. esteparum. One is S. dimorphum Lichtw. \& Williams from Boreoheptagyia lurida (Garrett) larvae (Diamesinae) collected in Rocky Mountain streams within and south of Glacier National Park, Montana and in the East River and Washington Gulch stream, Gunnison, Colorado (Lichtwardt and Williams 1983, 1988). The other is S. orthocladii Manier emend. Lichtw. reported from larval species of Orthocladius and Diamesa in southern France (Manier 1969), and from the same two genera of hosts in the Rocky Mountains of Montana, USA (Lichtwardt 1984).

Smittium tronadorium Lichtw., Ferrington et López

Lastra, sp. nov. $\quad$ Figs. 31-37

Thalli ad angulum acutum dense ramosi. Trichosporae elongato-ellipsoidales, parum ad medium tumidae, (15-) 23(-28) $\times$ 3-5 $\mu \mathrm{m}$, collaribus $1-3 \mu \mathrm{m}$ longis. Zygosporae ignotae. In proctodaeo Chironomidarum larvarum.

Thalli densely branched at acute angles. Trichospores long-ellipsoidal with a slight median bulge, (15-)23(-28) × 3-5 $\mu \mathrm{m}$, collars 1-3 $\mu \mathrm{m}$ long. Zygospores unknown. In hindgut of larval Chironomidae.

Etymology. After Tronador Glacier, near where the fungus was most abundant.

Specimens examined. ARGENTINA. RÍO NEGRO: unnamed tributary of Río Manso Superior, $41^{\circ} 12.1^{\prime} \mathrm{S}, 71^{\circ}$ 49.6' W, 17-XI-96, microscope slide ARG-24-5 (HOLOTYPE) prepared from hindgut of a Paraheptagyia larva (Diamesinae). (FH). Other specimens from the following sites (TABLE I) and hosts: Sites 12 (Cricotopus sp.) and possibly 10 (Cricotopus sp.), Chubut Province (Orthocladiinae larvae); Sites 17, 19, Neuquén Province (Diamesinae larvae); Site 24 (Paraheptagyia sp.) (Diamesinae), Río Negro Province (many larvae infected).

Cultures. ARG-24-2F (from P.araheptagyia sp. larva) 

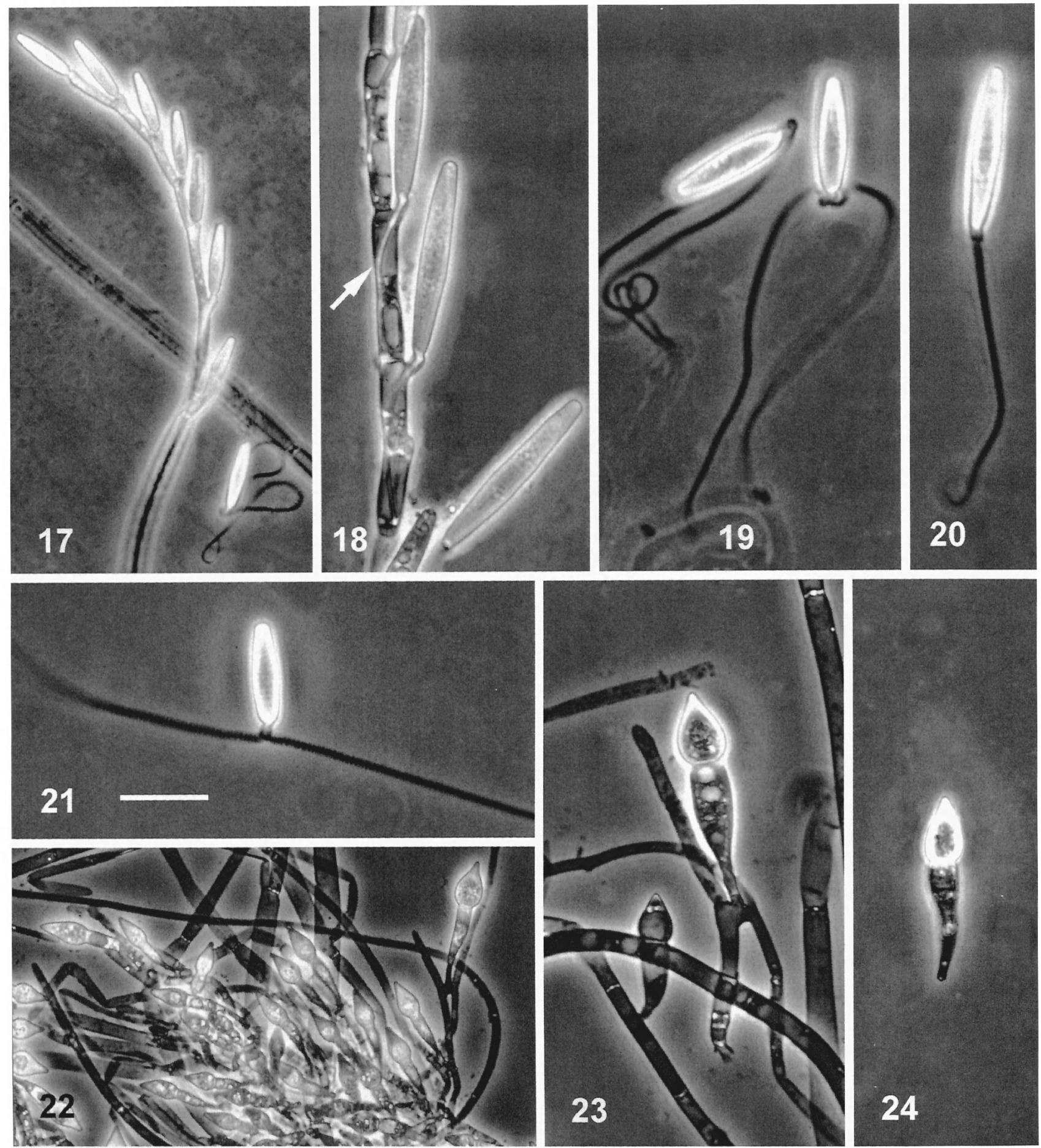

Figs. 17-24. Plecopteromyces patagoniensis. 17, 18. Thallial branches producing trichospores; the arrow points to an appendage visible within one of the generative cells. 19-21. Released trichospores, one with an apparent single appendage that probably represents a lack of separation of two appendages; note the almost beaded appearance of the appendages in 21 . 22. A mass of zygospores. 23, 24. Attached and detached zygospores showing their unique turbinate shape. Scale bar: 17,22 $=40 \mu \mathrm{m} ; 18-21,23,24=20 \mu \mathrm{m}$. 

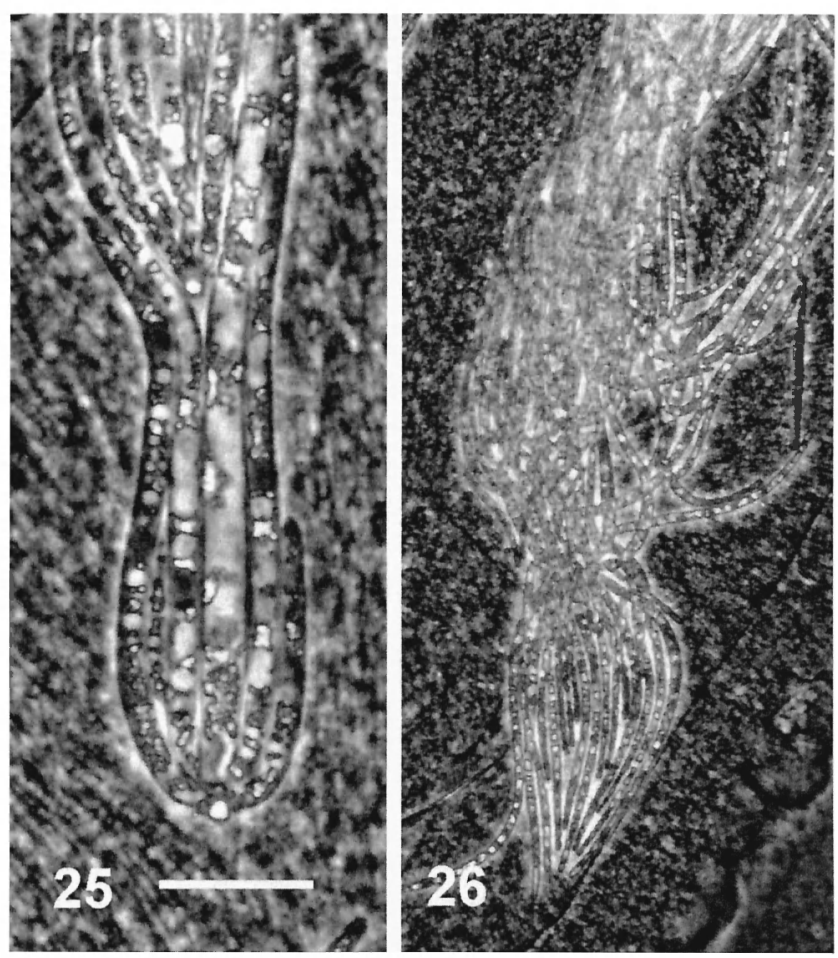

FIGs. 25, 26. Bases of Plecopteromyces patagoniensis thalli as seen within the hindgut. 25. Holdfast region of a young thallus. 26. More mature thallus showing growth from the base of multiple small branches oriented toward the anterior of the hindgut. Scale bar: $25=20 \mu \mathrm{m} ; 26=80 \mu \mathrm{m}$.

and ARG-2-20F (from Limaya? sp. larva) (Diamesinae). Two of six culture attempts were successful.

Diamesinae larvae collected at Site 24 included larvae of Paraheptagyia and a second species that showed similarities with both Paraheptagyia and $L i$ maya. The second species was smaller and lacked the strongly developed occipital margin characteristic of Paraheptagyia as described by Brundin (1966). The arrangement of anterior labral setae differed from the descriptions of both genera. Pupal exuviae matching Paraheptagyia cinerascens (Edwards) were collected at this site, along with smaller specimens that fit the diagnosis of Limaya, but differ from the species described by Brundin (1966).

The trichospore appendage of $S$. tronadorium, when fully extended, is very fine and long (FIG. 33), whereas unfurled appendages present a short, broad appearance (FIGs. 36, 37). Smittium tronadorium most closely resembles $S$. simulii Lichtw. and S. arvernense Poisson. However, both those species have different branching patterns and slightly different trichospore shapes, and S. simulii has a distinctive holdfast structure.
Stachylina platensis López Lastra, Lichtw. et Ferrington, sp. nov. FIGS. 38-41

Thalli $6-10 \mu \mathrm{m}$ diametro, e cellulis genitalibus 4 ad 32 compositi; cellulae genitales ubi multae perbreves. Trichosporae ellipsoidales parum ad medium tumidae, 25-36 $\times$ 5-7.8 $\mu \mathrm{m}$ collari satis brevi, appendicula una aliquando specie in partes duas fissa praeditae. Ad membranum peritrophicum larvarum Chironomidarum affixae.

Thalli 6-10 $\mu \mathrm{m}$ diam., consisting of 4 to more than 32 generative cells; generative cells may be very short when numerous. Trichospores ellipsoidal with a slight median bulge, 25-36 $\times 5-7.8 \mu \mathrm{m}$, with a very short collar and one appendage that sometimes appears to split into two. Attached to peritrophic membrane of Chironomidae larvae.

Etymology. From La Plata region.

Specimens examined. ARGENTINA. BUENOS AIRES: swamp in wooded area, Boca Cerrada at Punta Lara, $34^{\circ}$ $47.0^{\prime} \mathrm{S}, 58^{\circ} 00.7^{\prime} \mathrm{W}, 24 \mathrm{XI}-96$, microscope slide ARG-31-1 (HOLOTYPE) prepared from a Chironomus sp. larva. (FH). Other specimens: Stachylina platensis was first found in bloodworms (Chironomus sp.?) in 1995 from the same site as the holotype.

Stachylina is the second largest genus of Harpellales with 19 species, excluding $S$. platensis. The new species is most similar to $S$. euthena Manier \& Coste and $S$. grandispora Lichtw. both of which have been found in bloodworms. It differs in the following ways. Thalli of S. euthena range from 130-200 $\times 7-8 \mu \mathrm{m}$, bearing about 8 trichospores per thallus, and trichospores measure 25-35 $\times 7-8 \mu \mathrm{m}$ with an ephemeral collar 2.5-3 $\mu \mathrm{m}$ long. Thalli of $S$. grandispora are up to $250 \mu \mathrm{m}$ long by $6-10 \mu \mathrm{m}$ diam, and trichospores measure 40-72 $\times 6-10 \mu \mathrm{m}$ and a collar 1-3 $\mu \mathrm{m}$ long. Stachylina grandispora is a widespread species that lives in more than half a dozen chironomid hosts.

Stachylinoides Ferrington, Lichtw. et López Lastra, gen. nov.

Thallus haud ramosus ad basim infertilis, trichosporas sine collari et apppendicula unica praeditae. In Chironomidarum larvis.

Unbranched thallus not fertile near basal end, producing trichospores without a collar and with a single appendage. In Chironomidae larvae.

Etymology. Like Stachylina.

Type species. Stachylinoides arctata Ferrington, Lichtw. \& López Lastra.

Stachylinoides arctata Ferrington, Lichtw. et López Lastra, sp. nov. Figs. $42-45$

Thalli haud ramosi longitudinem $800 \mu \mathrm{m}$, diametrum 8$10 \mu \mathrm{m}$ attingentes. Thallorum basis rotundata, sine tenaculo secreto percepto. Trichosporae in dimidio thalli ter- 

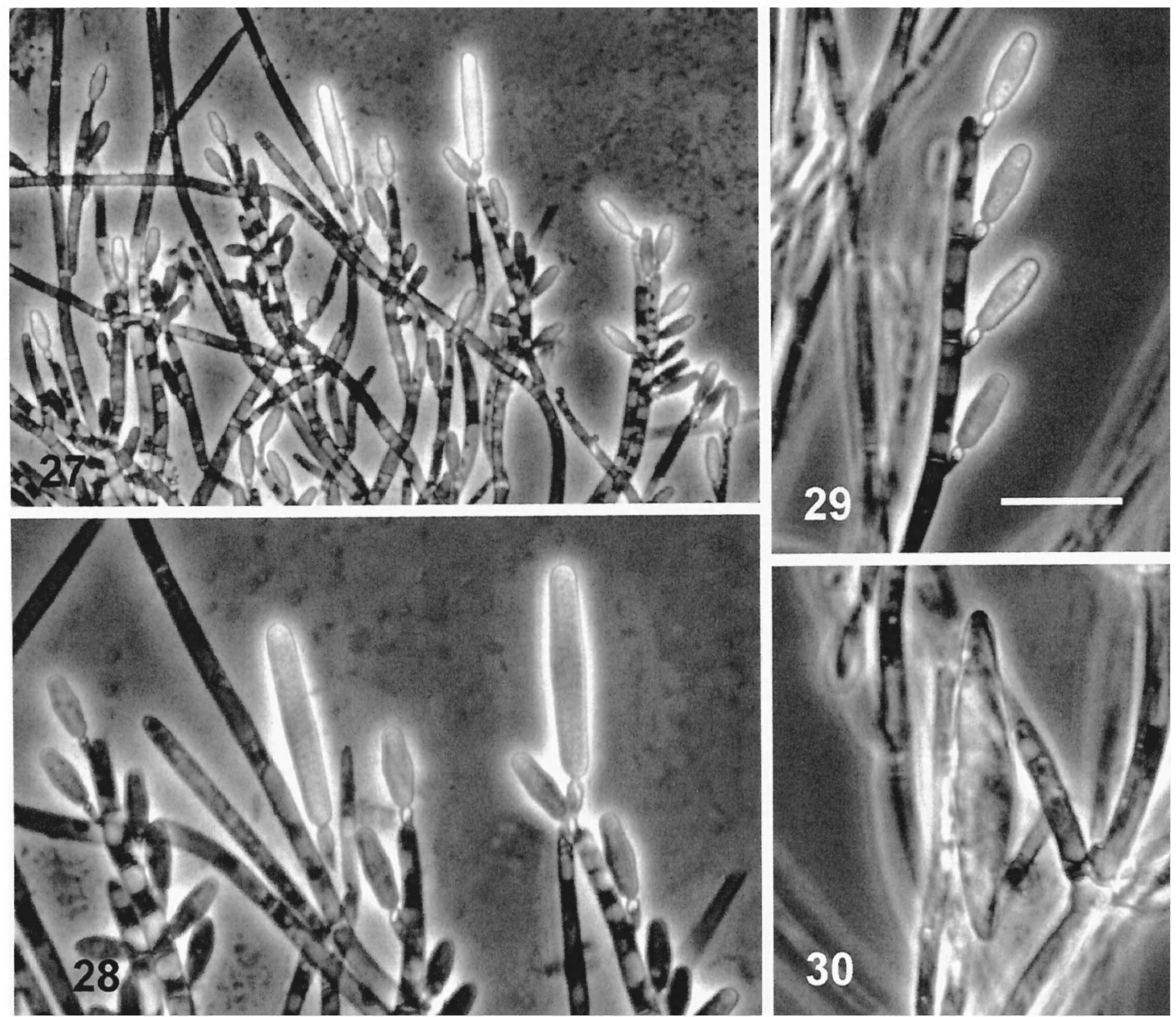

FIGs. 27-30. Smittium esteparum. 27, 28. Sporulating branchlets producing dimorphic trichospores. 29. Mature smaller trichospores. 30. Biconical zygospore. Scale bar: $27=40 \mu \mathrm{m} ; 28-30=20 \mu \mathrm{m}$.

minali productae, ovales, $10-15(-19) \times 5-7(-9) \mu \mathrm{m}$. In Chironomidarum larvis.

Unbranched thalli may be more than $800 \mu \mathrm{m}$ long by $8-10 \mu \mathrm{m}$ diam. Base of thalli rounded without a discernable secreted holdfast. Trichospores produced on terminal half of thallus, oval, 10-15(-19) $\times 5-7(-9) \mu \mathrm{m}$. In Chironomidae larvae.

Etymology. L. arctatus = confined (in the minute host's peritrophic membrane).

Specimens examined. ARGENTINA. NEUQUÉN: Arroyo Córdoba Grande, $40^{\circ} 30.8^{\prime} \mathrm{S}, 71^{\circ} 12.2^{\prime} \mathrm{W}, 12-\mathrm{XI}-96$, microscope slide $A R G-18-3 F$ (HOLOTYPE) made from the hindgut of a Thienemanniella sp. larva (Chironomidae: Orthocladiinae). (FH). Other specimen: larva of Thienemanniella sp. infected with $S$. arctata from Arroyo Gutiérrez, $41^{\circ} 08.0^{\prime}$ S, $71^{\circ} 25.0^{\prime} \mathrm{W}$, Río Negro Province, Argentina, 2-XI-96 (Site 4). ( $\mathrm{FH})$.

The main features that distinguish Stachylinoides from the more common and widespread genus Stachylina are as follows. Stachylina spp. are holocarpic; that is, the thallus becomes completely converted to generative cells each of which produces a tricho- spore. Also, in Stachylina the base of the thalli attach to the peritrophic membrane by producing either a disklike secreted structure, or by penetrating the membrane (see S. minuta, FIG. 83), depending on the species. Thalli of $S$. arctata are eucarpic, and do not produce generative cells in the basal part of the thallus (FIGS. 42-45); the base of the thallus has no evident means of attachment to the peritrophic membrane (FIG. 43).

Larvae of Thienemanniella are very small, usually 2-3 $\mathrm{mm}$ long when fully grown. We believe that a species of the same fungal genus was found in 1998 on South Island, New Zealand, in minute larvae of a related chironomid genus, Corynoneura (Ferrington, Slaymaker and Lichtwardt unpubl).

\section{Smittium sp.}

FIGS. $46-48$

What may be a new species of Smittium was cultured from an Orthocladiinae larva of the genus Apedilum Townes, as isolate ARG-12-1. This is the first 

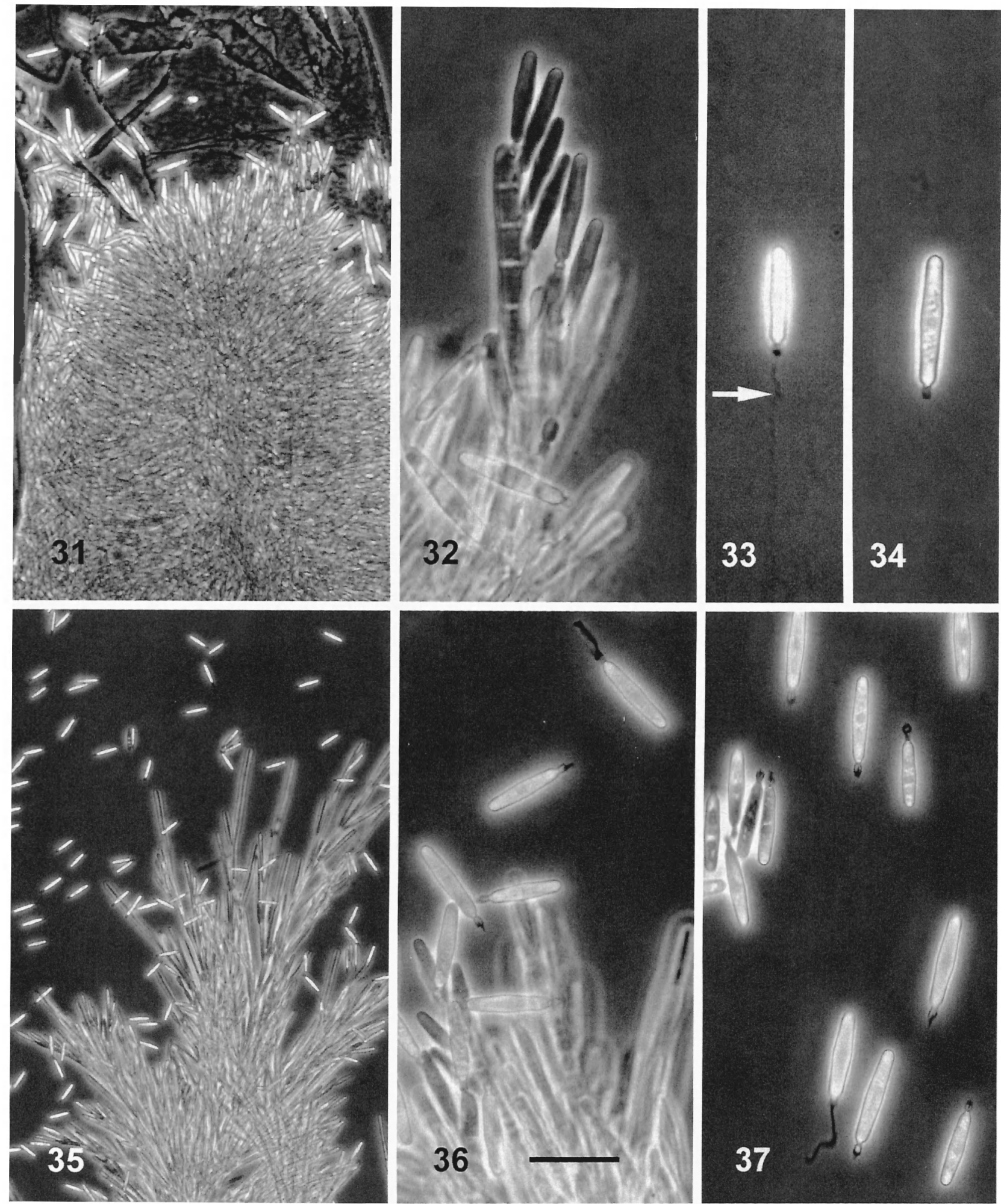

Figs. 31-37. Smittium tronadorium. 31. Dense growth of one thallus that fills the hindgut. 32-34. Trichospores, attached and detached; the arrow points to one fine, expanded appendage. 35-36. Branching pattern and released trichospores, one with an unextended appendage, from axenic culture ARG-24-2F. 37. Trichospores from axenic culture ARG-24-20F. Scale bar: $31,35=80 \mu \mathrm{m} ; 32-34,36,37=20 \mu \mathrm{m}$. 


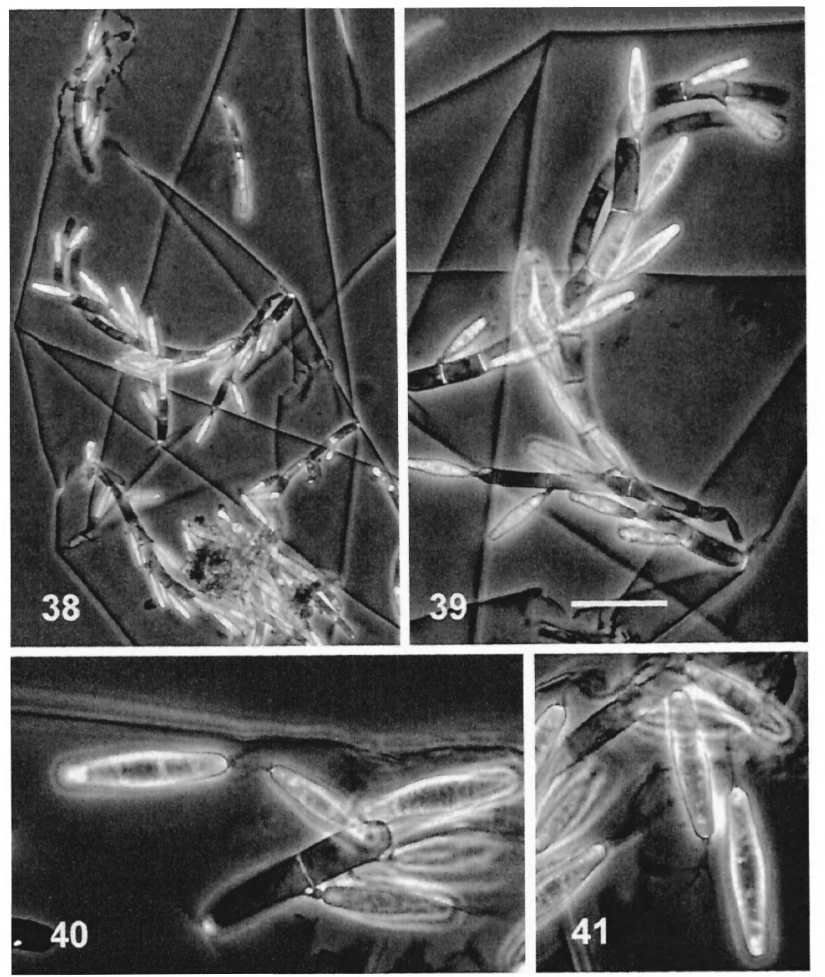

FIGS. 38-41. Stachylina platensis. Sporulating thalli with attached and released trichospores seen within the transparent peritrophic membrane of the chironomid host. Scale bar: $38=80 \mu \mathrm{m} ; 39=40 \mu \mathrm{m} ; 40,41=20 \mu \mathrm{m}$.

record of a trichomycete from the chironomid genus Apedilum. The culture subsequently was lost due to bacterial contamination. The fungal thalli produced a very dense growth both in vivo and in vitro. Trichospores were subcylindrical, measured 22-28 $\times 3$ $5 \mu \mathrm{m}$, and had a collar 4-5 $\mu \mathrm{m}$ long. Features of this species do not fit other described Smittium spp. The fungus is illustrated (FIGs. 46-48) but not named at this time because of insufficient material.

\section{Stachylina sp.}

FigS. 49-52

One larva of Cricotopus sp. from Arroyo Esquel in Chubut Province (Site 7) contained what is probably a new species of Stachylina, which is not formally named here because of insufficient specimens. The fungal thallus, with a small and inconspicuous holdfast, measured 90-140 × 8-10 $\mu \mathrm{m}$, and produced 212 ellipsoidal, collarless trichospores measuring 28$32 \times 7-9 \mu \mathrm{m}$, the first trichospore usually attached subterminally.

PREVIOUSLY KNOWN SPECIES

Genistellospora homothallica Lichtw.

Figs. 53-56

Genistellospora homothallica is widespread and rel-
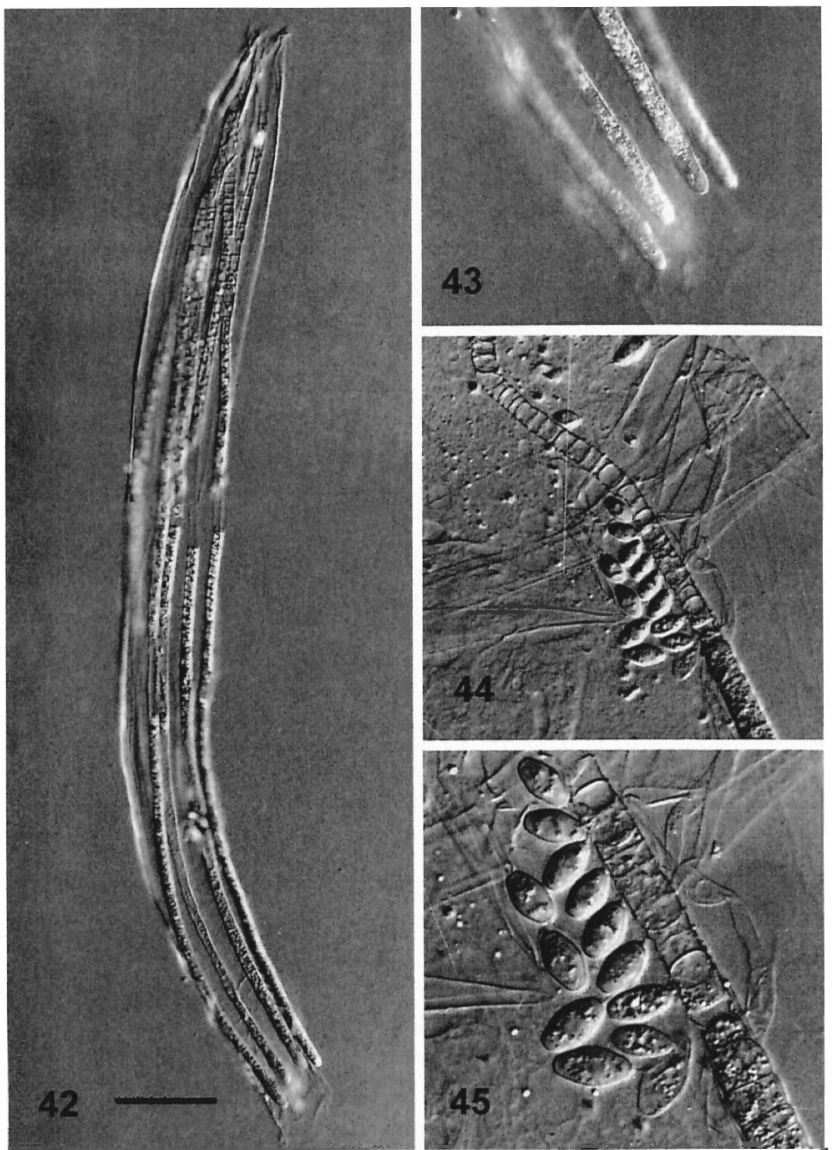

FIGs. 42-45. Stachylinoides arctata. 42. Composite of two photomicrographs showing an entire hindgut lining of a minute chironomid containing many unbranched thalli; the posterior end is at the top. 43. Basal ends of four thalli; note the apparent lack of a secreted holdfast. 44,45 . Cluster of trichospores that have emerged from their generative cells. Scale bar: $42=80 \mu \mathrm{m} ; 43,44=40 \mu \mathrm{m} ; 45=20 \mu \mathrm{m}$.

atively common in Simuliidae larvae in the USA, especially in the Rocky Mountains. It has been found rarely in the United Kingdom (Lichtwardt 1986), Spain (Girbal and Santamaria 1998), Costa Rica (Lichtwardt 1997), southern Chile (Lichtwardt and Arenas 1996), and now is reported from Buenos Aires Province in Argentina. It was found in simuliid larvae from Sites 41, 42, 43, 44, and 46a (TABLE I). López Lastra found this species in 1994 and 1995 in Simulium (Psaroniocompsa) bonaerense Coscarón \& Wygodzinsky from Arroyo Las Brusquitas, Buenos Aires Province, at Site 44. Genistellospora homothallica has ovoid trichospores (FIGs. 53, 54) that are (24-)30 $(-41) \times(8-) 10(-13) \mu \mathrm{m}$ with no collar and about 6 appendages. Zygospores (FIGS. 55, 56), which form without prior conjugations of branches, are (77-) 100 $(-113) \times(15-) 20(-22) \mu \mathrm{m}$. Genistellospora was a monotypic genus until three new species were found in Costa Rica (Lichtwardt 1997). 

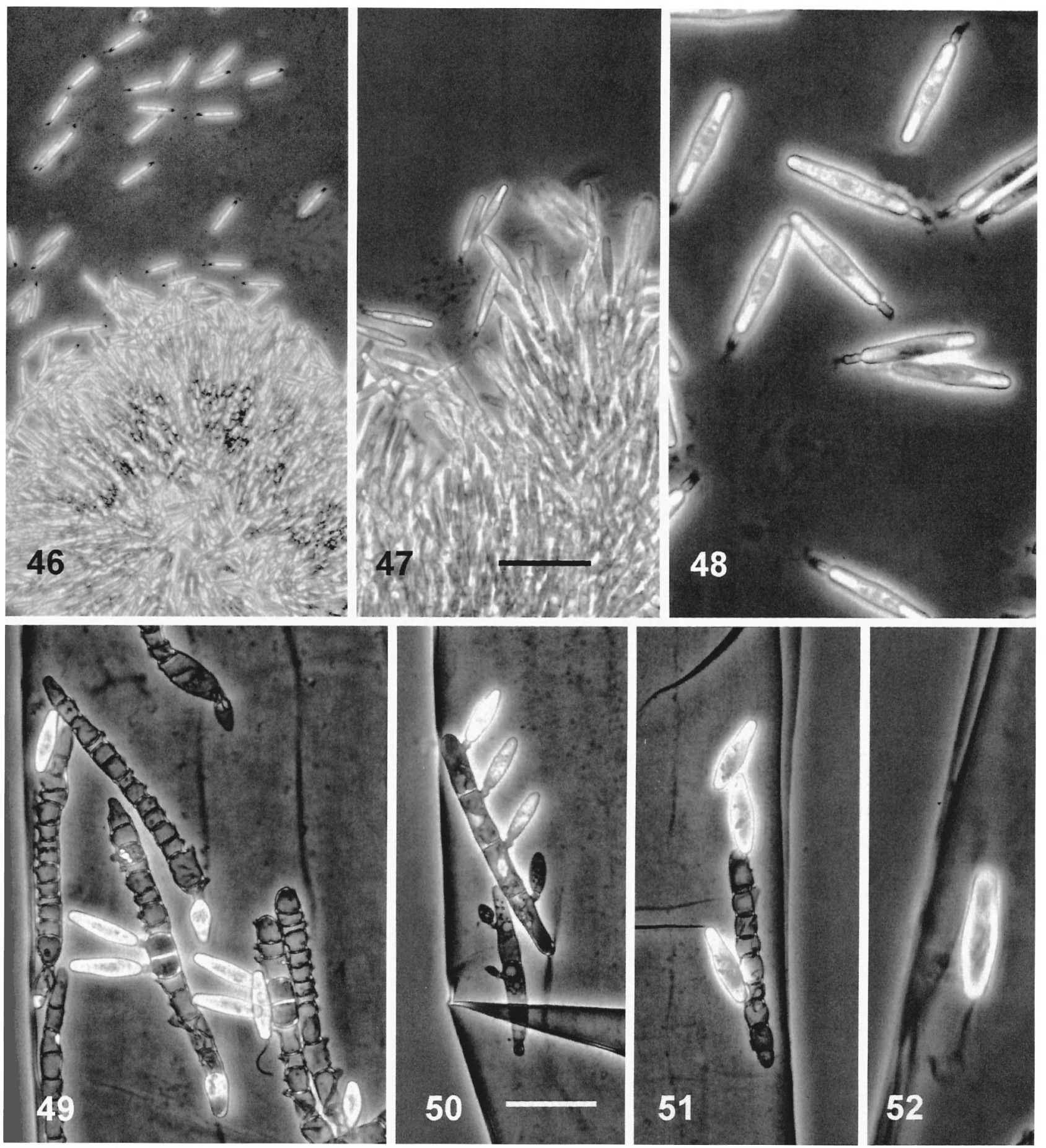

FIGS. 46-48. Smittium sp. Thalli and trichospores of an unnamed species that may be new. 49-52. Stachylina sp. Thalli and trichospores within the peritrophic membrane of a chironomid larva; this unnamed species is most probably new. Scale bar: $46=80 \mu \mathrm{m} ; 47,49,50=40 \mu \mathrm{m} ; 48,51,52=20 \mu \mathrm{m}$.

Harpella meridianalis Lichtw. \& Arenas FIGS. 57-61 Harpella meridianalis was present in almost all populations and most larvae of Simuliidae that were dissected. Sites with records of $H$. meridianalis included $2,3,4,6,9,11,17,18,20,21,25,41,42,43,44,46 a$, 46b (TABLE I). Simuliidae were available in most lotic habitats, but were not collected and dissected from all sites visited. Representative infected hosts that were identified included (numbers in parentheses are collection sites, TABLE I): Cnesia dissimilis (Edwards) (2, 3, 4), Gigantodax antarticus (Bigot) (2), Gigantodax marginalis (Edwards) (6), Gigantodax bro- 

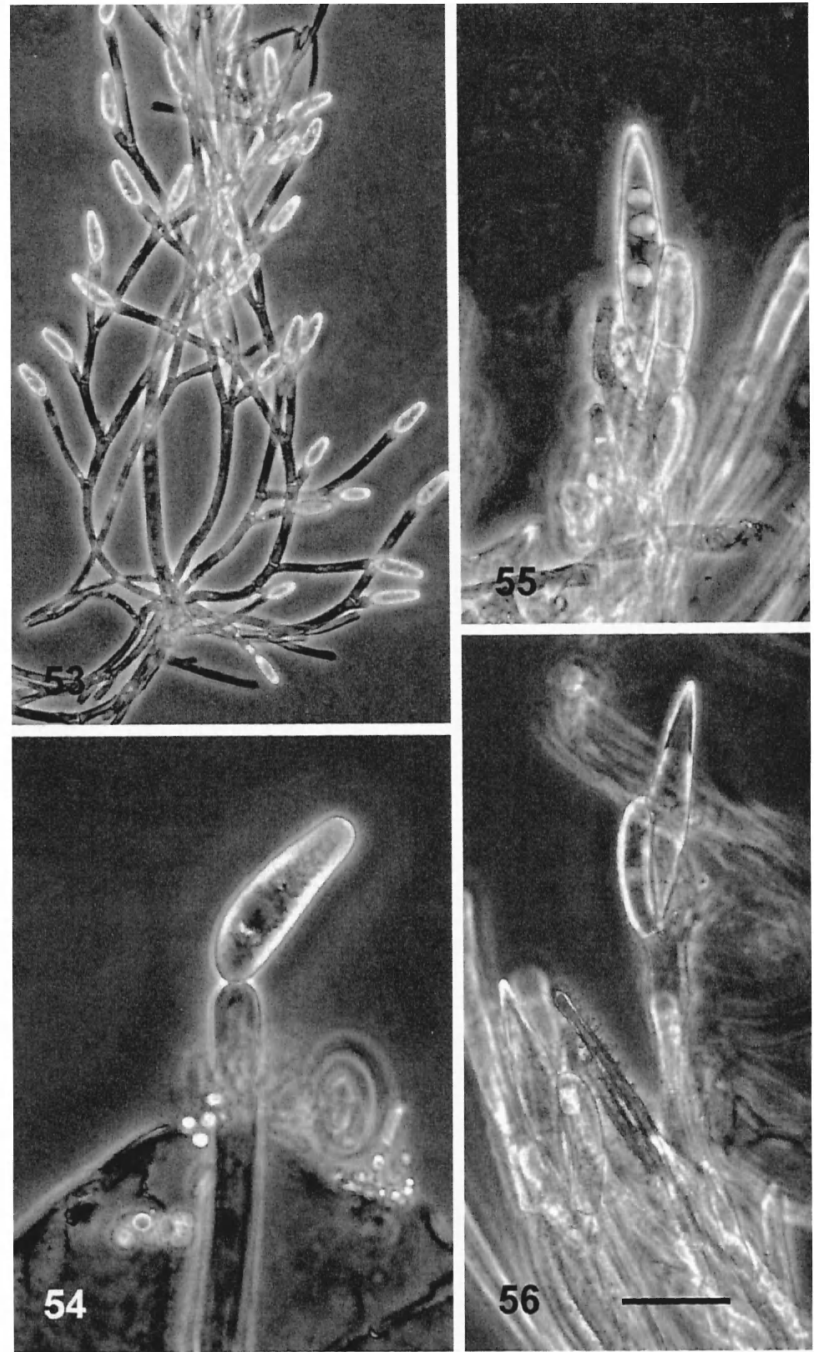

Figs. 53-56. Genistellospora homothallica. 53. Sporulating thallus. 54. Terminal trichospore. 55, 56. Zygospores. Scale bar: $53=80 \mu \mathrm{m} ; 54=20 \mu \mathrm{m} ; 55,56=40 \mu \mathrm{m}$.

phyi (?) (Edwards) (25), Gigantodax sp. (2), Simulium (Pternaspatha) sp. (4), Simulium (Psaroniocompsa) bonaerense (41, 42, 43, 44, 46a, 46b).

Harpella meridianalis was described from southern Chile (Lichtwardt and Arenas 1996). It may be biogeographically significant that this species has been found, to date, only in southern South America, to the apparent exclusion of the widespread species Harpella melusinae L. Léger \& Duboscq, a species which is known to infect simuliids in Australia and New Zealand, and in Japan, North America, Europe and other regions of the Northern Hemisphere (Lichtwardt 1986). Costa Rica in Central America appears to have solely the species, $H$. tica Lichtw. (Lichtwardt 1997). The fourth species of Harpella, H. leptosa Lichtw. \& S. T. Moss, is currently known only from northwestern Montana, U.S.A.

The Argentinean specimens fit the description of
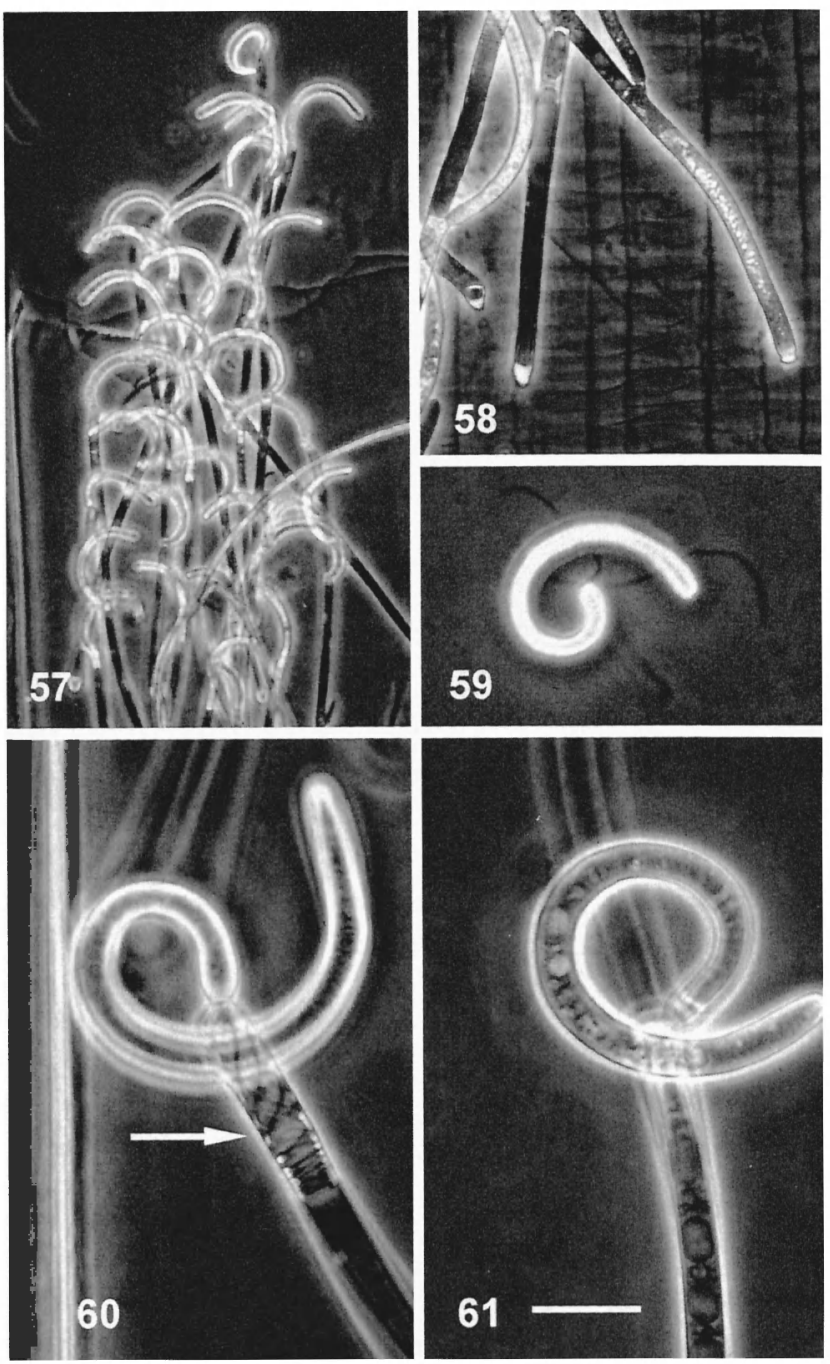

Figs. 57-61. Harpella meridianalis. 57. Numerous unbranched sporulating thalli attached within the peritrophic membrane of a simuliid larva. 58. Holdfasts attached to the peritrophic membrane. 59. Released trichospore with 4 appendages. 60, 61. Attached trichospores, one with focus on the appendages spiraled around the inner wall of the generative cell (arrow). Scale bar: $57=80 \mu \mathrm{m} ; 58,59=40$ $\mu \mathrm{m} ; 60,61=20 \mu \mathrm{m}$.

H. meridianalis, whose thalli have a rounded and broad secreted holdfast (Fig. 58) and measure approximately $200-320 \times 7-9 \mu \mathrm{m}$, producing curved to coiled trichospores $80-100 \times 4-8 \mu \mathrm{m}$ (FIGS. 59$61)$. We found some trichospores that measured slightly over $100 \mu \mathrm{m}$.

Simuliomyces microsporus Lichtw.

FIGS. 62-65

Simuliomyces microsporus is one of the most widespread species of Harpellales in various genera and species of Simuliidae larvae. It is known from various parts of the USA and Europe (Lichtwardt 1986), Aus- 
tralia (Lichtwardt and Williams 1990), Costa Rica (Lichtwardt 1997), and southern Chile (Lichtwardt and Arenas 1996). In Argentina it was found in Site 10 in Chubut Province, and 17 and 18 in Neuquén Province in Cnesia dissimilis (Edwards) and several unidentified simuliids. The fungus is often associated with Paramoebidium sp. (Amoebidiales) in simuliid hindguts, often attached to the terminal part of Paramoebidium thalli, as we found in Argentina. This attachment to Paramoebidium, or to thalli of other hindgut fungi in simuliids, is a clue to identification of $S$. microsporus, whose unreleased trichospores (FIG. 62), which, upon release, have 2-4 appendages rather than one as in Smittium, may otherwise be confused with Smittium spp. Zygospores of S. microsporus (FIGS. 63-65) are also different, being Type I (Moss et al 1975) instead of Type II as in Smittium spp. (e.g. Figs. 72, 73).

\section{Smittium culicis Manier}

Figs. 66, 67

Smittium culicis is a widespread, often culturable, species which, though found primarily in mosquito larvae (Culicidae), has an unusually wide host range representing six families of lower dipterans (Nematocera): Culicidae, Chironomidae, Simuliidae, Psychodidae, Thaumaleidae, and Tipulidae. Smittium culicis from Argentina was first reported by López Lastra (1997), and we have encountered it in several species of mosquitoes in the area of La Plata, Buenos Aires Province. The known hosts include Aedes albifasciatus (Macquart), Culex renatoi Lane \& Ramalho, and C. apicinus Philippi.

Cultures from Punta Lara (at Boca Cerrada, Ensenada) mosquitoes include an isolate from C. renatoi, 20-VI-96, and from A. albifasciatus, 2-V-96, deposited at USDA-ARS Collection of Entomopathogenic Fungi, Ithaca, New York, as ARSEF 5431 and 5432, and the Instituto Spegazzini, La Plata, Argentina; also deposited in the University of Kansas Culture Collection.

The species has oval trichospores measuring (15-) $20(-32) \times(4-) 6(-8) \mu \mathrm{m}$ with a usually campanulate collar (3-) 5-9 $\mu \mathrm{m}$ long. The base is pseudorhizoidal, which helps to distinguish it in vivo from other Smittiums with somewhat similar trichospores, such as $S$. culicisoides Lichtw. Zygospores of $S$. culicis have never been found.

\section{Smittium culisetae Lichtw.}

FIGS. 68,69

Smittium culisetae appears to have a worldwide distribution, and, like S. culicis, normally lives in mosquito larvae, but has been found in five families of Nematocera: Culicidae, Chironomidae, Simuliidae, Ceratopogonidae, and Tipulidae. It was once found in mayfly nymphs in an Australian rock pool coinhabited by mosquito larvae infected with the same species (Lichtwardt and Williams 1990). First reported from the region of La Plata, Buenos Aires Province by López Lastra (1997), it is now known to be relatively common. Known hosts of $S$. culisetae in the vicinity of La Plata are Aedes aegypti L., A. crinifer (Theobald), Culex castroi Casal \& García, C. dolosus (Lynch Arribálzaga), C. hepperi Casal \& García, C. pipiens Wiedemann, and Psorophora ferox (Humboldt).

Cultures of S. culisetae from Buenos Aires Province include isolates from Psorophora ferox and C. dolosus collected at Punta Lara, 10-XII-95 and 26-VI-96, deposited at USDA-ARS Collection of Entomopathogenic Fungi, Ithaca, New York, as ARSEF 5203, and Instituto Spegazzini, La Plata, Argentina as LPS 500; and other isolates from $A$. crinifer and $A$. aegypti deposited with López Lastra at CEPAVE and with R.W. Lichtwardt in the University of Kansas Culture Collection.

Smittium culisetae is one of the easiest species of Smittium to identify. The shape of the trichospores $[(11-) 16(-30) \times(3-) 4(-7) \mu \mathrm{m}]$ is long-ovoid (FIG. 69 ) with a short collar, and the branches are typically verticillate. Zygospores have been reported only from one site, in Nebraska, USA (Williams 1983).

Smittium cylindrosporum Lichtw. \& Arenas Figs. 70-73

Smittium cylindrosporum was known previously only from five streams located in southern Chile, living in larvae of Paraheptagyia cinerascens (Edwards) (Diamesinae) and Cricotopus sp. (Orthocladiinae) (Lichtwardt and Arenas 1996). We discovered this species in several Diamesinae larvae of Paraheptagyia sp. and Cricotopus sp. in a tributary of Río Manso Superior (Site 24, TABLE I) that drains the eastern Andes near Tronador Glacier. Pupal exuviae of Paraheptagyia cinerascens were collected at this site, and the larvae with growths of $S$. cylindrosporum match the description by Brundin (1966).

We report here for the first time zygospores of $S$. cylindrosporum (FIGs. 72, 73), which measured 51-52 $\times 10-11 \mu \mathrm{m}$. Trichospores are almost cylindrical, sometimes with a slight median bulge, and measure (21-)26-33(-41) $\times$ 4-6 $\mu \mathrm{m}$, with a collar 4-6 $\mu \mathrm{m}$ long. Trichospores in our specimens measured 29$39 \times 4-6 \mu \mathrm{m}$.

Chilean specimens yielded four axenic cultures (CHI-19-3, CHI-20-4, CHI-20-7, CHI-27-1) which were subsequently used in a comparative study of harpellid isozyme patterns (Grigg and Lichtwardt 1996), but we were not able to culture any of the Argentinean specimens. 

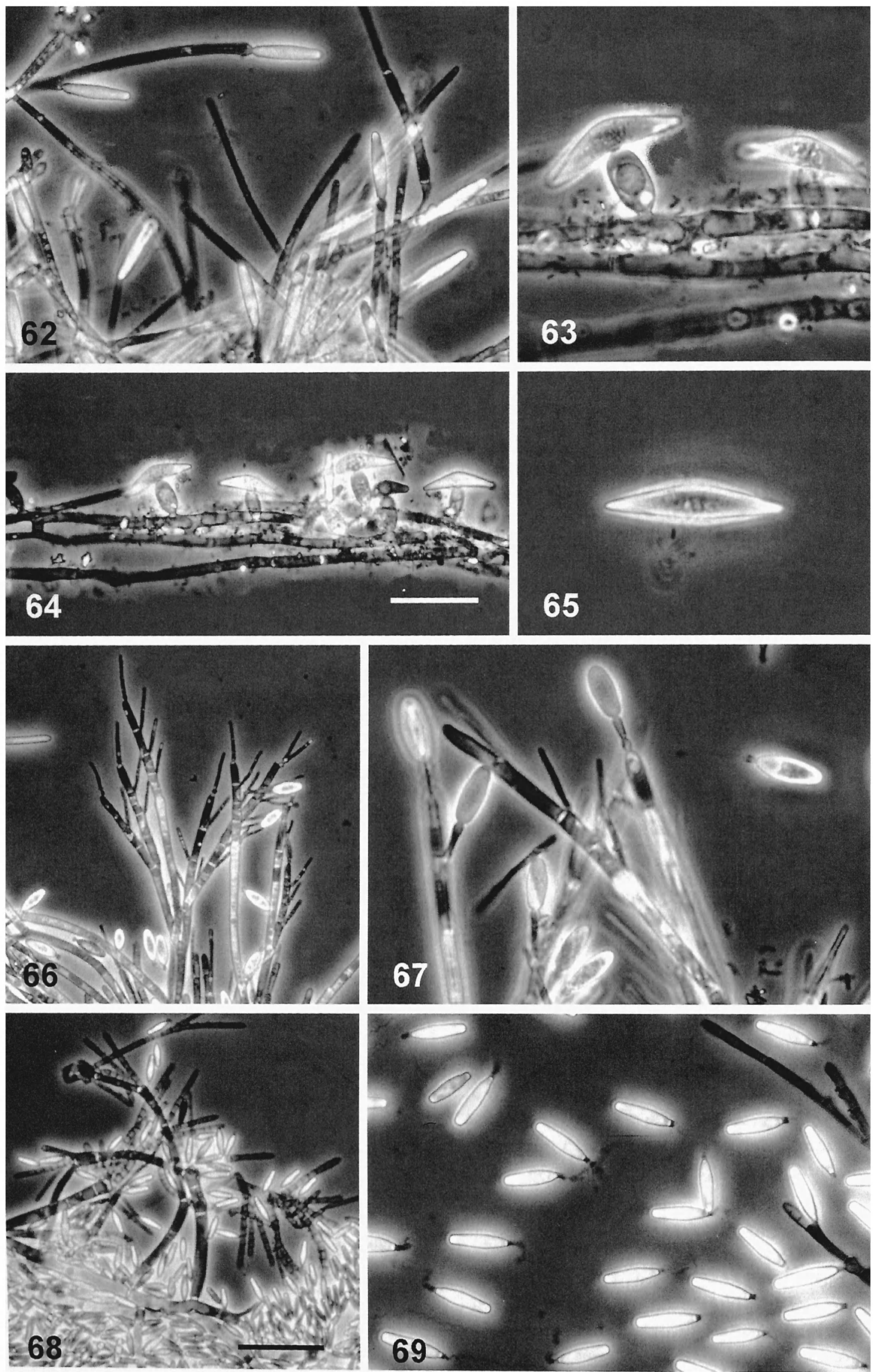
Smittium megazygosporum Manier \& Coste Figs. 74-80

Smittium megazygosporum was described by Manier and Coste (1971) from larvae of Syncricotopus rufventris Meig. (Chironomidae: Orthocladiinae) from southern France. We found in Argentina what we believe is the same fungus in another Orthocladiinae, Cricotopus sp., but without zygospores for full confirmation. The subcylindrical trichospores measured $40-47 \times 3.5-6.0 \mu \mathrm{m}$ with a collar 4-7 $\mu \mathrm{m}$ long (FIGs. 75-80). In our specimens, thalli were growing in tight clusters (FIG. 74) and had terminal branches that were often verticillate (FIG. 75), which are features of S. megazygosporum. We collected the fungus in Sites 4 and 10 (TABLE I).

Smittium cylindrosporum Lichtw. \& Arenas reported above, also from Cricotopus sp., has almost cylindrical trichospores (FIG. 71) that resemble those of $S$. megazygosporum, but they are shorter in size, as are the zygospores. The larvae from Site 10 also had another Smittium in the hindgut, possibly $S$. tronadorium.

Smittium morbosum Sweeney

Fig. 81

Other than Harpellales that grow into the ovaries of insects and lead to sterilization of the female (Labeyrie et al 1996, Lichtwardt 1996), Smittium morbos$u m$ is the only known trichomycete pathogen of insects. It was found by Sweeney (1981) killing a culture of mosquitoes in his laboratory, and had previously been found in Italy (Coluzzi 1966) and Russia (Dubitskii 1978) causing death of cultured mosquitoes. The first instance of pathogenicity by $S$. morbos$u m$ in natural populations of mosquitoes was in Japan (Sato et al 1989), but was then reported by López Lastra (1990) in Buenos Aires Province, and is now known to infect many species of mosquitoes in Argentina [Aedes albifasciatus, A. crinifer, A. serratus (Theobald), Anopheles annulipalpis Lynch Arribálzaga, Culex dolosus, C. intricatus Brèthes, C. maxi Dyar, C. pipiens, Mansonia indubitans Dyar \& Shannon, Psorophora ferox, and Uranotaenia nataliae Lynch Arribálzaga] (García et al 1994).

Infected mosquito larvae usually have a dark spot that is visible externally near the sixth abdominal segment caused by an internal melanization reaction where the fungus has penetrated the midgut epithelium. Sweeney (1981) was able to culture $S$. morbos$u m$, but up to now we have had no success in isolat-
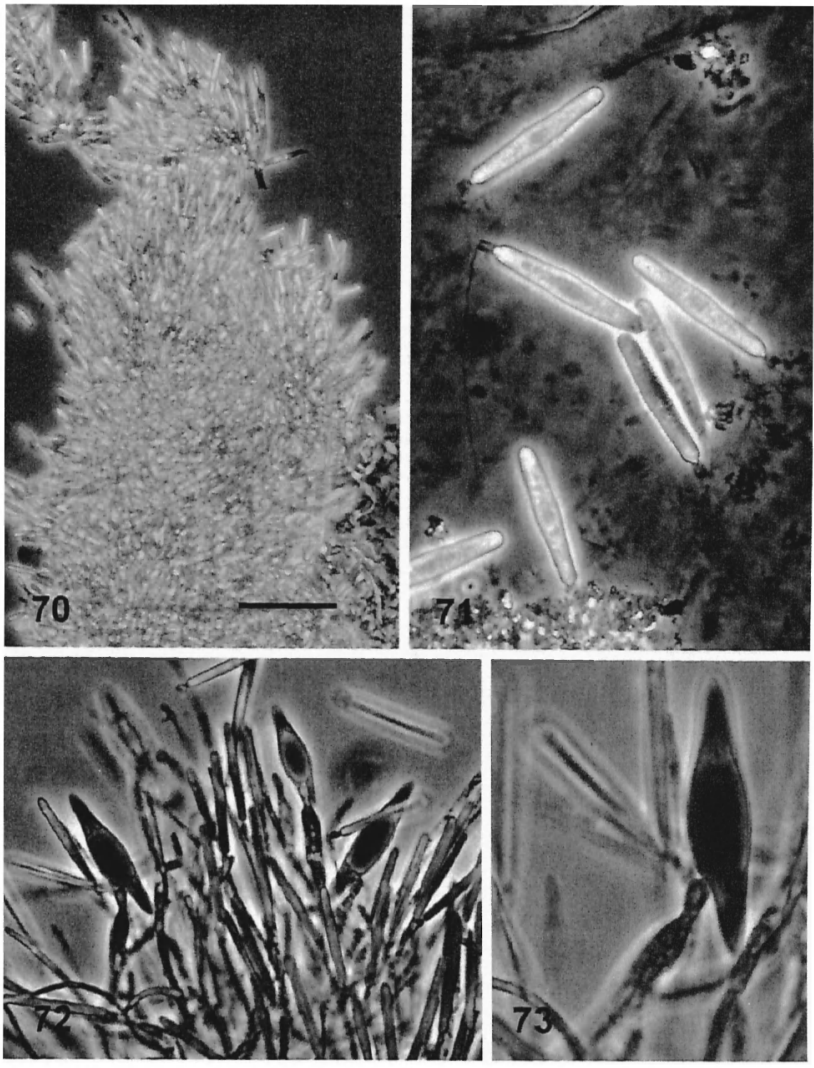

Figs. 70-73. Smittium cylindrosporum. 70. Dense growth of a single thallus. 71. Trichospores. 72, 73. Zygospores, previously unknown in the species. Scale bar: $70=80 \mu \mathrm{m} ; 71$, $73=20 \mu \mathrm{m} ; 72=40 \mu \mathrm{m}$

ing the fungus on artificial media. Trichospores are narrowly ellipsoidal, and measure (10-) $15(-18) \times$ $(3.5-) 4(-4.5) \mu \mathrm{m}$, with a very short collar. Zygospores are unknown.

Stachylina minima Williams \& Lichtw. FIGs. 82-86

Five species of Stachylina penetrate the peritrophic membrane of the larval dipteran midguts as a means of attachment, instead of producing a secreted holdfast. One of these, S. minima was described from Orthocladiinae (Chironomidae) larvae collected from several streams on South Island, New Zealand, and has been rediscovered in Argentina from Cricotopus sp. larvae (Orthocladiinae) from Arroyos Rodeo and Lepá in the estepas region of Chubut Province (Sites

FIGS. 62-69. Simuliomyces microsporus, Smittium culicis and Smittium culisetae. 62-65. Simuliomyces microsporus. 62. Trichospores produced by a thallus of $S$. microsporus that was attached to a thallus of Paramoebidium sp. (not shown). 63-65. Attached and released zygospores. 66-69. Two Smittium species from mosquito larvae. 66, 67. Two axenic cultures of $S$. culicis; these isolates are unusual in that they produce long extensions from some of the generative cells. 68, 69. Two axenic cultures of $S$. culisetae. Scale bar: $62,64,66,68=40 \mu \mathrm{m} ; 63,65,67,69=20 \mu \mathrm{m}$. 

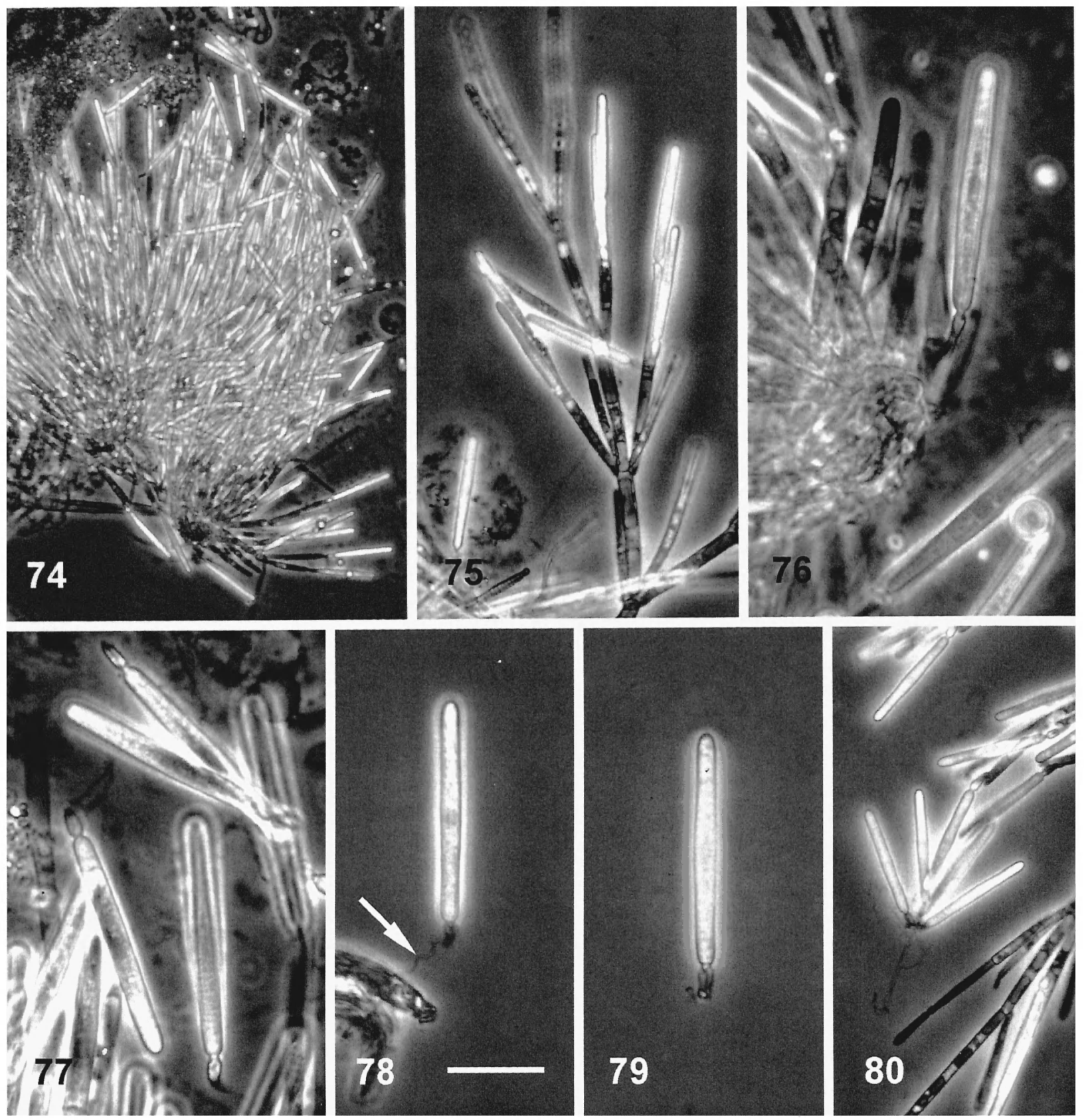

FIGs. 74-80. Smittium megazygosporum. 74. Compact thallus typical of this species. 75-79. Cylindrical trichospores, one with a very fine appendage in focus (arrow). 80. A cluster of trichospores held together by their appendages. Scale bar: 74 $=80 \mu \mathrm{m} ; 75.80=40 \mu \mathrm{m} ; 76-79=20 \mu \mathrm{m}$.

10, 12), and from Thienemanniella sp. (Orthocladiinae) larvae taken from a tributary of Río Traful in Neuquén Province (Site 17). Stachylina minima is a small species that produces 1-4 collarless, oval trichospores that measure (11-) $14(-18) \times 6-8 \mu \mathrm{m}$. Minute larvae of Thienemanniella sp. are also hosts of the new monotypic fungal genus Stachylinoides arctata described in this paper.
KEY TO SPECIES OF TRICHOMYCETES LIVING IN ARGENTINEAN AQUATIC INSECTS

1. Living in the hindgut of Coleoptera (beetle) larvae ................ Coleopteromyces amnicus

1. Living in other orders of insects .......... 2

2. Living in the hindgut of Plecoptera (stonefly) nymphs ................. 3 


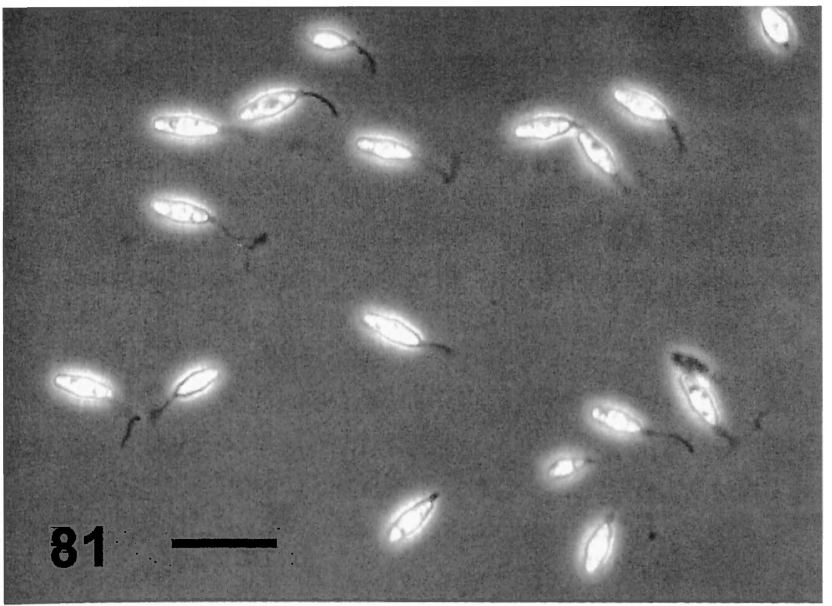

FIG. 81. Trichospores of Smittium morbosum. Scale bar $=20 \mu \mathrm{m}$.

2. Living in the midgut or hindgut of Diptera (Nematocera) fly larvae .............. 4

3. Thalli branched, producing trichospores (in Gripopterygidae) ....... Plecopteromyces patagoniensis

3. Thalli unbranched, not producing trichospores (in Notonemouridae) ...... Paramoebidium digitoideum

4. Branched thalli attached to hindgut cuticle ... 5

4. Unbranched thalli attached to midgut peritrophic membrane ............. 13
5. In Culicidae (mosquito) larvae $\ldots \ldots \ldots \ldots \ldots 6$

5. In Simuliidae (blackfly) or Chironomidae (midge) larvae ..................... 8

6. Pathogenic to host; trichospores ellipsoidal ... ................. Smittium morbosum

6. Not pathogenic; trichospores oval or ovoid ... 7

7. Trichospores oval with a long collar (>3 $\mu \mathrm{m}$ long) .................... Smittium culicis

7. Trichospores ovoid (wider near the base) with a short collar $(<3 \mu \mathrm{m}$ long $) \ldots \ldots$ Smittium culisetae 8. In Simuliidae larvae ............... 9

8. In Chironomidae larvae $\ldots \ldots \ldots \ldots \ldots \ldots$

9. Often attached of thalli of Paramoebidium or other trichomycetes in the hindgut; holdfast not obvious; trichospores ellipsoidal, $<7 \mu \mathrm{m}$ wide, upon release having 2 or 4 appendages ......... ................ Simuliomyces microsporus

9. Thalli always attached to hindgut cuticle by an obvious secreted holdfast; trichospores ovoid, $>7 \mu \mathrm{m}$ wide, upon release having about 6 appendages . . . ................ Genistellospora homothallica 10. Producing dimorphic trichospores (having two different shapes and sizes) ... Smittium esteparum

10. Trichospores not dimorphic . . . . . . . 11

11. Trichospores long-ellipsoidal, usually $<25 \mu \mathrm{m}$ long ............... Smittium tronadorium

11. Trichospores almost cylindrical, usually $>25 \mu \mathrm{m}$

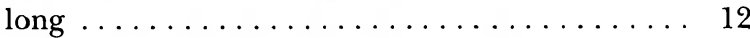
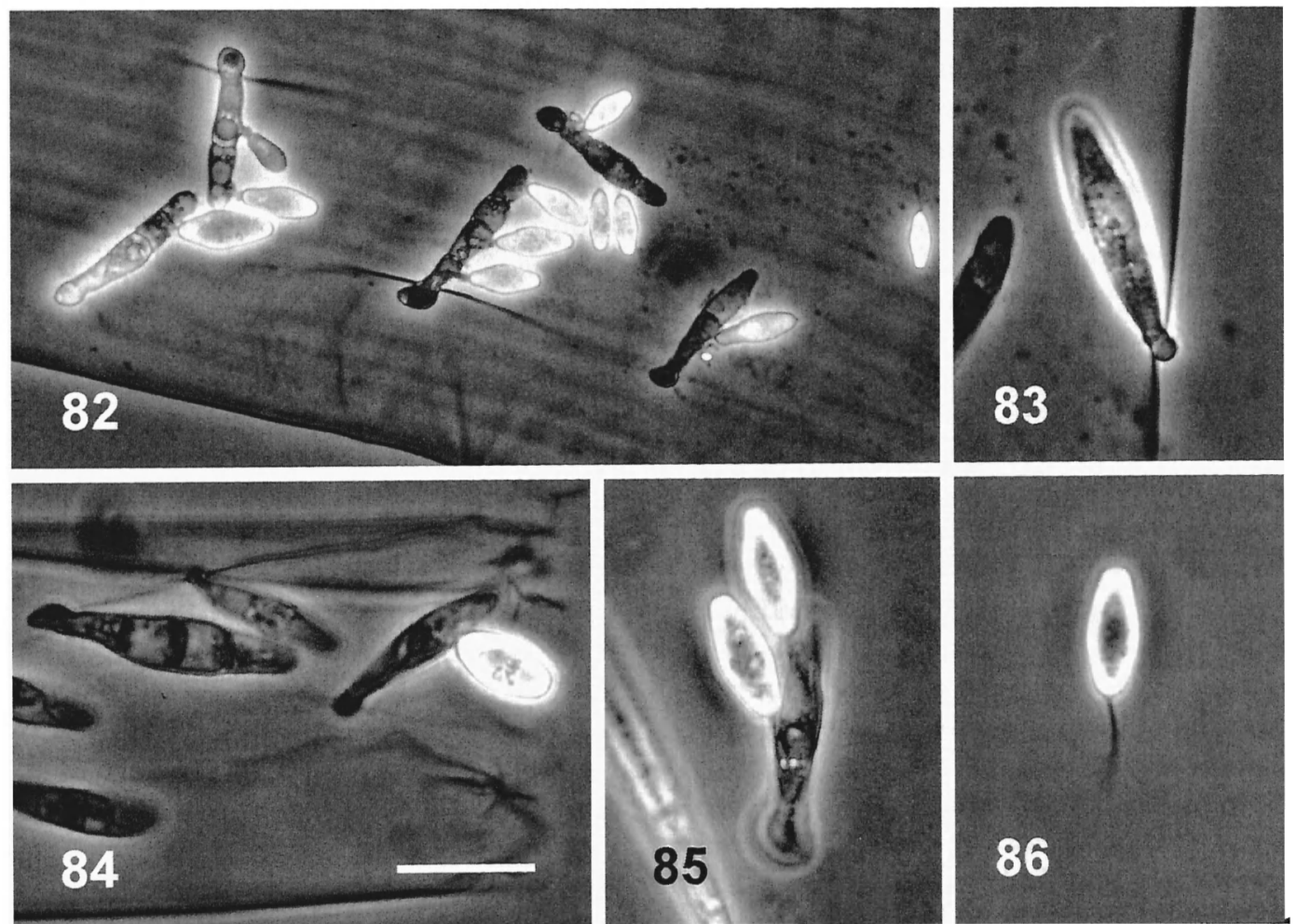

FIGS. 82-86. Stachylina minima. Thalli and trichospores seen within the peritrophic membrane of a chironomid larva; 83 shows the base of a developing thallus penetrating the membrane, which is typical in this species. Scale bar: $82=40 \mu \mathrm{m}$; $83-86=20 \mu \mathrm{m}$. 
12. Trichospores usually $26-33 \mu \mathrm{m}$ long ..... .............. Smittium cylindrosporum

12. Trichospores usually $40-47 \mu \mathrm{m}$ long ..... ............. Smittium megazygosporum

13. Attached to hindgut of Ceratopogonidae (biting midge) larvae .......... Carouxella coemeteriensis

13. Attached to peritrophic membrane of Simuliidae or Chironomidae larvae .............. 14

14. Attached to peritrophic membrane of Simuliidae larvae; trichospores cylindrical and curved to coiled ............ Harpella meridianalis

14. Attached to peritrophic membrane of Chironomidae larvae; trichospores ellipsoidal or oval . . . . . . . 15

15. Basal part of thallus remains sterile (produces no trichospores) ........... Stachylinoides arctata

15. Entire thallus becomes reproductive . . . . . . 16

16. Thallus penetrates peritrophic membrane, producing 1-4 oval trichospores without a collar ................. Stachylina minima

16. Thallus attaches to peritrophic membrane, with 4-32 generative cells that produce ellipsoidal trichospores with a minute collar ......... $\ldots \ldots \ldots \ldots \ldots$ Stachylina platensis

\section{DISCUSSION}

Considering the wide range of biomes and habitats throughout Argentina and the species richness that we encountered in the limited sites listed in TABLE I, it is evident that even the 19 species we report in this paper are but a small part of the trichomycete mycota that is yet to be discovered in Argentina. Our explorations included the Pampeana biogeographic region in Buenos Aires Province, the Patagonica region in the more southern Provinces consisting of estepas and mixed forests in the lower Andes, leading to the edge of the Subantartica region at higher altitudes in the Andes (Cabrera and Willink 1973).

The cooler waters of the three Patagonian Provinces (Río Negro, Chubut, Neuquén) had a considerably richer insect fauna than the warmer lotic waters of Buenos Aires Province that we sampled, which in turn contained a greater variety of gut fungi. The southern streams ranged from 5.0-14 C (av. 9.5 C), whereas the more northern streams we sampled had temperatures of 19.5-27.0 C (av. 22.4 C). The only abundant trichomycete hosts in most of those warmer streams were Simuliidae, consisting of one species. A number of Simuliidae larvae in the warmest stream, Arroyo El Perdido (Site 47), were infected with an unidentified species of Smittium, but no Harpella meridianalis was found. The latter fungus was almost universally present in Simuliidae from cooler waters.

Collections of surface floating pupal exuviae of Chironomidae were taken at each sample site in $\mathrm{Pa}$ - tagonia concurrently with larvae for dissection. These samples show a high diversity of species, predominantly Orthocladiinae and Diamesinae, emerging from most streams sampled. Podonominae were common in smaller streams, especially those with very minimal growth of periphyton. Several new types of Orthocladiinae pupae collected are similar to undescribed exuviae illustrated by Cranston (1996) from Australia. These exuviae will be described and illustrated in a subsequent publication, but they reinforce the circumantartic relationship of Heptagyiini and Podonominae reported by Brundin (1966).

Two of the new monotypic genera we have described from Patagonia, Plecopteromyces from Gripopterygidae stonefly nymphs and Stachylinoides from Thienemanniella midge larvae, appear to be genera that we have previously found in New Zealand and Australia, but those species remain to be described. Specimens of what appear to be a second species of Stachylinoides were found in the midgut of larvae of Corynoneura in streams on South Island, New Zealand.

The genus Carouxella has an interesting disjunct distribution. The type species, C. scalaris Manier \& Lichtw. was first described from the ceratopogonid species Dasyhelea lithotelmatica Strenzk and Dasyhelea sp. inhabiting potholes and rock fissures in southern France (Manier et al 1961, Manier and Lichtwardt 1968). What appeared to be the same species of Car ouxella (but lacking zygospores for confirmation) was found by Lichtwardt and Williams (1990) in rock potholes in New South Wales, Australia, in a new, undescribed species of Dasyhelea. In Argentina we found the new fungal species described in this paper, C. coemeteriensis, in another new species of Dasyhelea, D. necrophila, inhabiting flower vases in the La Plata cemetery. Undoubtedly Carouxella spp. will be found in other habitats, but will they all infect larvae of the ceratopogonid genus Dasyhelea?

Another apparent disjunct distribution is found in the mosquito pathogen, Smittium morbosum. Although first described and cultured axenically by Sweeney (1981) in Australia, the fungus apparently had been found previously killing mosquito larvae in Italy (Coluzzi 1966) and Russia (Dubitskii 1978). The first record of $S$. morbosum infections in natural populations of mosquitoes was in Japan (Sato et al 1989). In the La Plata region in Argentina the pathogen has been found in five genera and 10 species of mosquitoes (López Lastra 1990, García et al 1994). Although mosquitoes have been widely studied by entomologists, invertebrate pathologists, and mycologists seeking Trichomycetes (Lichtwardt 1986), it is interesting that the above reports appear to be the only ones on S. morbosum. 
Known hosts of Harpellales consisted of lower Diptera (Nematocera), Plecoptera, and Ephemeroptera prior to our studies in Argentina. Discovery of $\mathrm{Co}$ leopteromyces amnicus in Scirtidae (Coleoptera) larvae in Patagonia has added a new order of insects to the host range. More recently White (1999) reported finding Harpellales in aquatic Isopoda (Crustacea) and larval caddisflies (Diptera: Trichoptera) in New England, USA. These discoveries emphasize that our knowledge of the species richness, host range, and biogeographical distribution of aquatic gut fungi is an ever progressing endeavor.

\section{ACKNOWLEDGMENTS}

We thank the National Science Foundation for providing support of this project with a PEET award, DEB-9521811. We are very grateful to Sixto Coscarón for identifying Simuliidae, Ricardo Albariño (Gripopterygidae), Gustavo Spinelli (Ceratopogonidae), and Juan José García (Culicidae). We acknowledge the following persons for facilitation of insect specimen collecting: Irma Gamundí, Julieta Massaferro, and Diego Añon Suarez, Centro Nacional Universitario, Bariloche; and Mario Rajchemberg, CIEFAP, Esquel. Don Rogers kindly provided the Latin translations. Collecting in the National Parks was done with permission from Administración de Parques Nacionales, Argentina. We appreciate the comments and suggestions of Merlin White, Matías Cafaro, and Alexandra Gottlieb who reviewed the manuscript.

\section{LITERATURE CITED}

Brundin L. 1966. Transantarctic relationships and their significance, as evidence by chironomid midges with a monograph of the subfamilies Podonominae and Aphroteniinae and the austral Heptagyiae. Kungl Svenska Vetenskapsakademiens Handlingar. Fjärde Ser Band II Nr 1. 472 p.

Cabrera AL, Willink A. 1973. Biogeografia de America Latina. Washington, DC: Organización de los Estados Americanos. 120 p.

Campos RE, Maciá A, García JJ. 1995. Variación estacional de las poblaciones de Psorophora spp. (Diptera: Culicidae) y detección de sus parásitos y patógenos en la Provincia de Buenos Aires, Argentina. Acta Entomol Chilena 19:113-121.

Coluzzi M. 1966. Experimental infections with Rubetella fungi in Anopheles gambiae and other mosquitoes. In: Corradetti A, ed. Proc First Intern Congr Parasitol (Rome) 1964, Vol 1. New York: Pergamon Press. p 592-593.

Cranston PS. 1996. Identification guide to the Chironomidae of New South Wales. CSIRO Div Entomol, Australian Water Technologies Pty Ltd, AWT Identification Guide Number 1. 376 p.

Dubitskii AM. 1978. Biological control of blood sucking Diptera in the USSR. Alma Ata: Inst Zool Kazakhstan Acad Sci. 267 p.
García JJ, Campos RE, Maciá A. 1994. Prospección de enemigos naturales de Culicidae (Diptera) de la selva marginal de Punta Lara (Prov. de Buenos Aires, República Argentina). Rev Acad Colombiana Ciencias Exactas Nat 19:209-215.

1995. Observaciones ecológicas sobre Mansonia indubitans y Ma. titillans (Diptera: $\mathrm{Cu}-$ licidae) y sus enemigos naturales en Punta Lara, Argentina. Rev Soc Entomol Argentina 54:43-50.

Girbal J, Santamaria S. 1998. Trichomycetes (Fungi, Zygomycotina) comensals de larves de Simuliidae (Diptera) a la Península Ibèrica. Acta Bot Barc 45:49-56.

Grigg R, Lichtwardt RW. 1996. Isozyme patterns in cultured Harpellales. Mycologia 88:219-229.

Horn BW, Lichtwardt RW. 1981. Studies on the nutritional relationship of larval Aedes aegypti (Diptera: Culicidae) with Smittium culisetae (Trichomycetes). Mycologia 73: 724-740.

Labeyrie ES, Molloy DP, Lichtwardt RW. 1996. An investigation of Harpellales (Trichomycetes) in New York State blackflies (Diptera: Simuliidae). J Invert Path 68: 293-298.

Lichtwardt RW. 1984. Species of Harpellales living within the guts of aquatic Diptera larvae. Mycotaxon 19:529550 .

- 1986. The Trichomycetes, fungal associates of arthropods. New York: Springer-Verlag. 343 p.

- 1996. Trichomycetes and the arthropod gut. In: Howard D, Miller, D, eds. The Mycota, animal and human relations. Berlin: Springer-Verlag. p 315-330.

- 1997. Costa Rican gut fungi (Trichomycetes) infecting lotic insect larvae. Rev Biol Trop 45:1349-1383.

- - Arenas J. 1996. Trichomycetes in aquatic insects from southern Chile. Mycologia 88:844-857.

-_- Williams MC. 1983. Two unusual Trichomycetes in an aquatic midge larva. Mycologia 75:728-734.

- - 1988. Distribution and species diversity of trichomycete gut fungi in aquatic insect larvae in two Rocky Mountain streams. Can J Bot 66:1259-1263.

-, 1990. Trichomycete gut fungi in Australian aquatic larvae. Can J Bot 68:1057-1074.

López Lastra CC. 1990. Primera cita de Smittium morbosum var. rioplatensis var. nov. (Trichomycetes: Harpellales) patógeno de 5 especies de mosquitos (Diptera: Culicidae) en la República Argentina. Rev Argent Micol 13: 14-18.

1997. Primera cita de Smittium culisetae y S. culicis (Trichomycetes: Harpellales) en larvas de mosquitos (Diptera: Culicidae) de la República Argentina. Bol Soc Argent Bot 33:43-46.

Maciá A, García JJ, Campos RE. 1995. Bionomía de Aedes albifasciatus y Ae. crinifer (Diptera: Culicidae) y sus enemigos naturales en Punta Lara, Buenos Aires. Neotrópica 41:43-50.

1996-1997. Variación estacional de tres especies de Culex (Diptera: Culicidae) y sus parásitos y patógenos en Punta Lara, provincia de Buenos Aires, Argentina. Rev Biol Trop 44/45:267-275. 
Manier J-F. 1969 (1970). Trichomycètes de France. Ann Sci Nat Bot Biol Vég, Sér 12 10:565-672.

- Coste F. 1971. Trichomycètes Harpellales de larves de Diptères Chironomidae; création de cinq nouvelles espèces. Bull Soc Mycol France 87:91-99.

, Lichtwardt RW. 1968. Révision de la systématique des Trichomycètes. Ann Sci Nat Bot Biol Vég, Sér 129: 519-532.

, Rioux J-A, Whisler HC. 1961. Rubetella inopinata $\mathrm{n}$. sp. et Carouxella scalaris n. g., n. sp., Trichomycètes parasites de Dasyhelea lithotelmatica Strenzke, 1951 (Diptera Ceratopogonidae). Naturalia Monspeliensia, Ser Bot 13:25-38.

Moss ST, Lichtwardt RW, Manier, J-F, 1975. Zygopolaris, a new genus of Trichomycetes producing zygospores with polar attachment. Mycologia 67:120-127.

Sato H, Shimada N, Aoki J. 1989. Light and electron microscopy of Smittium morbosum (Trichomycetes), newly recorded from Japan. Trans Mycol Soc Japan 30:51-59.

Sweeney AW. 1981. An undescribed species of Smittium (Trichomycetes) pathogenic to mosquito larvae in Australia. Trans Br Mycol Soc 77:55-60.

White MM. 1999. Legerioides, a new genus of Harpellales in isopods and other Trichomycetes from New England, USA. Mycologia 91:1021-1030.

Williams MC. 1983. Zygospores in Smittium culisetae (Trichomycetes) and observations on trichospore germination. Mycologia 75:251-256. 